\title{
Plant extracts as corrosion and scale inhibitors: A review
}

\author{
B.A. Abd-El-Nabey, ${ }^{1}$ D.E. Abd-El-Khalek, ${ }^{2}$ S. El-Housseiny ${ }^{3}$ \\ and M.E. Mohamed ${ }^{1 *}$ \\ ${ }^{1}$ Faculty of Science, Chemistry Department, Alexandria University, P.O. Box 426, \\ Alexandria 21321, Egypt \\ ${ }^{2}$ Marine Chemistry Department, National Institute of Oceanography and Fisheries, \\ Elanfoshy, Alexandria, Egypt \\ ${ }^{3}$ Faculty of Science, Chemistry Department, Kuwait University, Kuwait \\ *E-mail: elshahatchemist93@gmail.com
}

\begin{abstract}
The definition, classification, properties, chemical composition and uses of plant extracts were reported in this review article. Corrosion of metals and alloys influences infrastructures, buildings, industrial economy, modern and old ancient works. Protection of metals and alloys against corrosion can be achieved by using different methods such as cathodic protection, environmental control, anticorrosion coatings and adding inhibitors. Plant extracts were studied as low cost eco-friendly corrosion inhibitors. They not contain heavy metals or other toxic compounds. In addition they are biodegradable and renewable source of materials. Plant extracts were classified into inhibitors for corrosion of the following metals and alloys in different aggressive corrosion media: carbon steel, aluminium and its alloys, copper and its alloys, zinc and its alloys and nickel and its alloys. Mineral scale deposits in industrial water represent a major problem leading to unexpected shutdowns and costly chemical or cleaning actions. Control of scale formation including acidification, ion exchange softening and scale inhibitors addition. The environment concerns lead the research to develop new environmentally friendly chemicals, currently named "Green" scale inhibitors. Plant extracts are recently used as green antiscalents and classified into inhibition of crystallization of each of carbonates and sulphates.
\end{abstract}

Keywords: corrosion inhibitors, antiscalants, plant extracts, steel, aluminium, copper, nickel.

Received: June 28, 2020. Published: October 23, 2020

doi: $\underline{10.17675 / 2305-6894-2020-9-4-7}$

\section{Plant extracts}

It is estimated that there are 250,000 to 500,000 species of plants on Earth $[1,2]$, and botanists are still discovering around 2000 more every year [3]. The majority of the plants used by humans are dedicated to medicine, phytotherapy in particular. A passing fad for some, medicine for others, this traditional practice is based on the use of the natural therapeutic properties of plants in treating pathologies. Although it is the oldest care technique in existence, it has been supported by various types of research (clinical and 
pharmacological). In particular, its success arises from a deeper understanding of plants and from a qualitative selection of varieties.

A plant extract is a substance or an active with desirable properties that is removed from the tissue of a plant, usually by treating it with a solvent, to be used for a particular purpose. Plant extraction is solid/liquid extraction, eventually followed by purification stages. It is thus defined as an operation of the separation of one or several constituents (solid or liquid) contained in a solid object by solubilisation in a fluid. This fluid, generally known as a solvent, may be a liquid or a gas (water vapour or supercritical fluids).

Plants contain many types of chemical constituents such as: alkaloids, glycosides, organic acids, resins (including resin acids, resin alcohols and hydrocarbon resins), volatile oils, sugars (including starches, inulin, gums and phlegmatic, etc.), amino acids, proteins and enzymes, tannins, plant pigments (including chlorophyll, carotenoids, flavonoids, beet red bases and quinones, etc.), oils and waxes, and inorganic ingredients (trace elements) $[4,5]$.

According to the formulations of plant extracts, it can be divided into: water-soluble plant extracts (including water and propylene glycol, propylene glycol, butylene glycol, and glycerol extract), oil-soluble plant extracts (including various vegetable oils, such as the exact of sunflower oil, coconut oil and olive extract oil, sometimes use isopropyl myristate extract), essential oils, spray-dried powder, enzyme-hydrolyzed vegetable protein powder, the pure active ingredients, peeled fruit core powder, liposome encapsulated microcapsules, polysaccharides or other porous polymer-encapsulated microcapsules and microspheres absorbed extract. It has been also used of freshly prepared fruit or vegetable juice in the professional beauty salon or family. If the plant parts used for the plant extract are different, the active ingredients are also different, including: roots, stems, leaves, bark, flowers, garland, fruits, seeds, shoots and the like. This classification method is more meaningful in the preparation, application, storage and transportation, and is used frequently by the manufacturer of some plant extracts.

According to markets and markets analysis, the plant extracts market is estimated to be valued at USD 23.7 billion in 2019 and is projected to reach USD 59.4 billion by 2025, at a CAGR of $16.5 \%$ from 2019 to 2025 [6].

Besides nutrition and pharmaceutical purposes, plant extracts were used also in many applications. For example, the biosynthesis of silver nanoparticles (Ag NPs) using extract of Salvia spinosa [7]. Antimicrobial assay verified bactericidal activity of biosynthesized Ag NPs against Gram-positive and Gram-negative bacteria. According to the results, by growing the plants under controlled conditions, it is feasible to synthesize nanoparticles with desired properties. Moreover, Cassiolato et al. [8] estimated the efficiency of plant extract to neutralize soil acidity. Three laboratory methods were evaluated: $\Sigma(\mathrm{Ca}+\mathrm{Mg}+\mathrm{K})$ of the plant extracts; electrical conductivity of the plant extracts and titration of plant extracts with $\mathrm{NaOH}$ solution between $\mathrm{pH} 3$ to 7 . These methods were compared with the effect of the plant extracts on acid soil chemistry. All laboratory methods were related with soil reaction. Increasing $\Sigma(\mathrm{Ca}+\mathrm{Mg}+\mathrm{K})$, electrical conductivity and the volume of $\mathrm{NaOH}$ solution spent to 
neutralize $\mathrm{H}^{+}$ion of the plant extracts were correlated with the effect of plant extract on increasing soil $\mathrm{pH}$ and exchangeable $\mathrm{Ca}$ and decreasing exchangeable Al. During the last years, plant extracts were employed as scale inhibitors in many industrial applications in order to develop new cleaning chemicals for green environment.

\section{Plant extracts as corrosion inhibitors}

Corrosion of metals and alloys influences industrial economy, infrastructures, buildings, modern and ancient artworks. Due to atmospheric interaction and exposure to aggressive environments, such as $\mathrm{NaCl}$ and acid solutions, metals and alloys undergo corrosion. Corresponding to the spontaneous return of metals to their ores. Protection of metals against corrosion can be achieved by using different methods such as; cathodic protection, anticorrosion coating and commercial inhibitors. Various organic compounds have been used as corrosion inhibitors through adsorption on to the surface of the metals and alloys. The adsorption of corrosion inhibitors on the metal surface retards the anodic and/or cathodic reaction rates through forming passive film and/or changing the mechanism of corrosion. Unfortunately, most of the organic inhibitors are expensive and non-degradable which results in environmental pollution upon discharging. Recently, the increasing interest of the environmental preservations oriented many research efforts to replace the organic inhibitors with environmentally friendly materials. Plant extracts were studied as low cost and eco-friendly corrosion inhibitors; they also not contain heavy metals or other toxic compounds [9-11]. In addition, they are biodegradable and renewable source of materials. Plant extracts contain organic compounds such as tannin, organic and amino acids, alkaloids and pigments; they exhibit inhibitory action [12-14].

\section{II.1. Plant extracts as inhibitors for corrosion of carbon steel}

Carbon steel has excellent mechanical properties, good ductility, toughness, weldability and low cost, hence it can be used in different applications [15]. Typical applications include; pipelines, structural shapes, automobile body components, ships, bridges, tin cans etc. [16]. However, in many applications the corrosion results in the destruction and degradation of steel, minimizing its lifetime. One of the most effective and economic methods to protect metals against corrosion is using inhibitors.

\section{II.1.a. Plant extracts as inhibitors for corrosion of carbon steel in acid media}

G. Gunasekaran et al. (2004) [17] studied he inhibitive effect of Zanthoxylum alatum plant extract on the corrosion of mild steel in 20,50 and $88 \%$ aqueous phosphoric acid using weight loss and electrochemical impedance spectroscopy technique. The extract was able to reduce the corrosion of steel more effectively in $88 \%$ than in $20 \%$ phosphoric acid. Results indicated that this extract is effective up to $70^{\circ} \mathrm{C}$. Surface analysis (XPS) and (FT-IR) were carried out to analyses the mechanism of corrosion inhibition of mild steel in phosphoric acid media. 
K.O. Orubite et al. (2004) [18] studied the inhibitive action of the extract of the leaves of Nypa fruticans Wurmb on the corrosion of mild steel in hydrochloric acid solution using weight loss and hydrogen gas evolution techniques. The highest of $75.18 \%$ was observed.

The effect of extracts of Chamomile (Chamaemelum mixtum L.), Halfabar (Cymbopogon proximus), Black cumin (Nigella sativa L.), and Kidney bean (Phaseolus vulgaris L.) plants on the corrosion of steel in $1 \mathrm{M} \mathrm{H}_{2} \mathrm{SO}_{4}$ solution were studied by A.M. Abd-El-Gaber et al. (2006) [19] using potentiodynamic polarization and electrochemical impedance spectroscopy techniques. The potentiodynamic results indicated that all extracts act as efficient mixed-type inhibitors. The inhibitive action of plant extracts was discussed on the basis of adsorption of stable complex at the steel surface. Theoretical fitting of different isotherms: Langmuir, Flory-Huggins and Kinetic-thermodynamic model were tested to clarify the nature of adsorption.

The inhibitive action of aqueous extract of garlic peel on the corrosion of carbon steel in $1 \mathrm{M} \mathrm{HCl}$ was studied by S.S.A.A. Pereira et al. (2012) [20]. The mechanism of the inhibition was discussed on the basis of the adsorption of the sulphur compound in the extract on the steel surface. The experimental results of adsorption fits Langmuir isotherm.

K. Krishnveni et al. (2013) [21] studied the inhibitive properties of the Morinda tinctoria plant leaves extract in the corrosion of steel in acid medium using colorimetric, weight loss, AC impedance and Tafel polarization techniques. The extract act as mixed-type inhibitor and the process of inhibition is through charge transfer.

The inhibitive action of chitosan extracted from Archachatina marginata shells on the corrosion of plain carbon steel in acid media was studied by A.E. Okoronkwo et al. (2014) [22] using weight loss and thermometric methods. Characterization of the obtained chitosan was obtained with Fourier transform infrared spectroscopy analysis. The results indicated that chitosan has good inhibition efficiency of $93.2 \%$.

The inhibitive effect of the aqueous extract of Musa paradisica (Banana) peels on mild steel corrosion in $1 \mathrm{M} \mathrm{HCl}$ was studied by G. Ji (2015) [23] using weight loss, electrochemical impedance spectroscopy, Tafel polarization and atomic force microscopy techniques. The adsorption behavior of the extract was studied and the results indicated that, the adsorption process of the extract is controlled by Langmuir adsorption isotherm.

Pomegranate (Punica granatum) peel extract as green corrosion inhibitor for mild steel in hydrochloric acid solution was studied by H. Ashassi-Sorkhabi et al. (2015) [24] using weight loss, polarization and electrochemical impedance techniques. The results indicated that this extract is an efficient green inhibitor for corrosion of mild steel in $\mathrm{HCl}$ solution.

The inhibitory effect of Gentiana olivieri extract on the corrosion of mild steel in $0.5 \mathrm{M}$ $\mathrm{HCl}$ was investigated by E. Baran et al. (2016) [25] using potentiodynamic polarization and electrochemical impedance spectroscopy techniques. Impedance results showed maximum inhibition efficiency of $93.7 \%$ at $800 \mathrm{ppm}$ of the extract. Potentiodynamic polarization results showed that the extract act as a mixed-type inhibitor.

Phyllanthus amarus leaf extract has been investigated as a corrosion inhibitor for mild steel in $1 \mathrm{M} \mathrm{HCl}$ solution by K.K. Anupama et al. (2016) [26] using weight loss, 
potentiodynamic polarization and electrochemical impedance spectroscopy techniques. As concentration of the extract increased, inhibition efficiency also increased and finally reached $95 \%$ at $303 \mathrm{~K}$. The quantum mechanical parameters well explained the effect of standard features on the electron donating ability of Phyllanthus.

The inhibitive effect of Leptadenia pyrotechnica extract on the corrosion of mild steel in $\mathrm{H}_{2} \mathrm{SO}_{4}$ solution was studied by G. Singh et al. (2016) [27] using weight loss and thermometric techniques. The results indicated that the extract gave inhibition efficiency of 87.04 at $0.8 \%$ extract in $1 \mathrm{~N} \mathrm{H}_{2} \mathrm{SO}_{4}$.

The inhibitive effect of the extract of the leaves of Alhagi maurorum, Morus nigra and Apricot leaves extracts on the corrosion of steel in $0.5 \mathrm{M} \mathrm{H}_{2} \mathrm{SO}_{4}$ solution were studied by B.A. Abd-El-Nabey et al. (2016) [28] using weight loss, thermometric, potentiodynamic polarization and electrochemical impedance spectroscopy techniques. Effect of solvent of extraction on the inhibition efficiencies of the three extracts were discussed. Theoretical kinetic-thermodynamic model of adsorption of the extract on the steel surface was tested to fit the experimental data. The activation parameters of the corrosion reaction of steel with $\mathrm{H}_{2} \mathrm{SO}_{4}$ in the absence and presence of the three extracts were determined. The correlation between the thermodynamic and kinetic data and molecular structure of the chemical constituents of the three extracts were discussed.

Inhibition of the corrosion of mild steel in $1 \mathrm{M} \mathrm{HCl}$ solution by Lemon Balm extract was studied by N. Asadi et al. (2018) [29] using electrochemical and theoretical approaches. According to the electrochemical impedance spectroscopy results the maximum inhibition efficiency of $95 \%$ was obtained in a solution containing $800 \mathrm{ppm}$ extract. The excellent corrosion inhibition effect of the extract on mild steel in $\mathrm{HCl}$ solution was related to the adsorption of active inhibitive compounds such as caryophyllene, germacrene, citral, luteolin, chlorogenic acid and rosmarinic acid on the mild steel surface.

Synergistic corrosion inhibition effect of rice husk extract and KI for mild steel in $\mathrm{H}_{2} \mathrm{SO}_{4}$ was studied by M. Pramudita et al. (2019) [30] using weight loss method. The adsorption of KI increased the efficiency of the extract and the highest efficiency was $95.89 \%$ at $1250 \mathrm{ppm}$. The experimental results indicated that, the adsorption process of the extract obeys Langmuir adsorption isotherm.

Peganum harmala seed extract was examined as corrosion inhibitor for mild steel in $\mathrm{HCl}$ solution by $\mathrm{G}$. Bahlakeh et al. (2019) [31] using potentiodynamic polarization and electrochemical impedance spectroscopy techniques. The presence of many electron donor atoms based on nitrogen and oxygen in the molecules of Peganum harmala seed extract is responsible for its effective adsorption behavior on the metal surface through chelation with iron atoms. Increase in the concentration of the extract and time of immersion leads to an increase of the inhibition efficiency up to $95 \%$.

The inhibitory behavior of Mustard seed extract for mild steel in $1 \mathrm{M} \mathrm{HCl}$ solution was investigated by G. Bahlakeh et al. (2019) [32] using weight loss, potentiodynamic polarization and electrochemical impedance spectroscopy techniques. The impedance results proved that the maximum inhibition efficiency reached $94 \%$ for $200 \mathrm{ppm}$ of the extract. The 
study of adsorption isotherm showed that, the adsorption of Mustard seed extract molecules obeyed Langmuir isotherm.

The inhibition effect of Parsley (Petroselinum sativum) leaves extract on mild steel in $1 \mathrm{M} \mathrm{HCl}$ solution was investigated by M. Benarioua et al. (2019) [33] using weight loss, potentiodynamic polarization, electrochemical impedance spectroscopy and scanning electron microscopy. The inhibition efficiency increased with increase of the extract concentration up to $92.39 \%$ at $500 \mathrm{ppm}$. Polarization results showed that the extract acts as a mixed-type inhibitor and obeys Langmuir adsorption isotherm.

Borage flower aqueous extract as an environmentally sustainable corrosion inhibitor for acid corrosion of mild steel was studied by A. Dehghani et al. (2019) [34] using potentiodynamic polarization and electrochemical impedance spectroscopy techniques. The impedance results showed that, with the increase in Borage flower extract content in $\mathrm{HCl}$ solution and immersion time the inhibition efficiency achieved $91 \%$ at $500 \mathrm{ppm}$ after 5 hours.

Tamarindus indica aqueous extract as a new green inhibitor for mild steel corrosion in acidic media was studied by A. Dehghani et al. (2019) [35] using potentiodynamic polarization, electrochemical impedance spectroscopy, scanning electron microscopy and contact angle measurements. Impedance measurements showed maximum inhibition efficiency of $93 \%$ at $800 \mathrm{ppm}$ extract after 2.5 hours steel immersion in aggressive media. The adsorption of the extract molecules on the steel surface was controlled by Langmuir isotherm.

V.C. Anadebe et al. (2019) [36] studied the application of pigeon pea leaf extract as anti-corrosion agent for mild steel in $\mathrm{HCl}$ solution. The work involved investigation of the corrosion inhibition process using combination of experimental, theoretical modeling and optimization studies. The inhibition efficiency of $87.13 \%, 91 \%, 92.1 \%$ and $90.7 \%$ were obtained from the experimental studies of thermometric, gravimetric, potentiodynamic polarization and electrochemical impedance spectroscopy techniques respectively.

Ziziphora leaves extract was examined as green inhibitor for acidic corrosion of mild steel by A. Dehghani et al. (2020) [37]. The structure of extract photochemical was characterized by Fourier transform infrared spectroscopy (FT-IR) and ultraviolet-visible (UV-Vis) spectroscopy. Electrochemical impedance spectroscopy analysis indicated that, this extract up to $800 \mathrm{ppm}$ gave inhibition efficiency of 93\% (after 2.5 hours). The polarization results showed that, the extract act as mixed-type inhibitor and its adsorption on the steel surface obeys Langmuir adsorption isotherm.

Dardagan Fruit extract was examined as ecofriendly corrosion inhibitor for mild steel in $1 \mathrm{M} \mathrm{HCl}$ by A. Sedik et al. (2020) [38] using electrochemical techniques. The surface techniques; scanning electron microscope, atomic force microscopy, energy dispersive x-ray spectroscopy, contact angle measurements was also performed to get information about the surface properties of mild steel. The results indicated that this extract has good protection efficiency for corrosion of mild steel in acid medium, it gave $92 \%$ inhibition efficiency after 1 hour and 97\% after 6 hours immersion in 3000 ppm extract. 
The extract of Terminalia chebula was examined as eco-friendly inhibitor for corrosion of carbon steel in acid media by A. Saxena et al. (2020) [39]. This extract showed great corrosion inhibition at specific concentration. The surface morphology of steel was studied using scanning electron microscopy and atomic force spectroscopy. The experimental results fits the Langmuir adsorption isotherm.

A. Saxena et al. (2020) [40] studied the inhibition characteristics of Musa acuminata for corrosion of low carbon steel in $0.5 \mathrm{M} \mathrm{H}_{2} \mathrm{SO}_{4}$ using weight loss, potentiodynamic polarization and electrochemical impedance spectroscopy techniques. The results indicated that, this extract showed an effective corrosion inhibition for corrosion of low carbon steel in acid media.

\section{II.1.b. Plant extracts as inhibitors for corrosion of carbon steel in neutral and alkaline media}

Silene marmarica was studied as an environmentally friendly inhibitor for steel corrosion in $0.5 \mathrm{M} \mathrm{H}_{2} \mathrm{SO}_{4}$ by O.A. Abdullatef et al. (2015) [41] using potentiodynamic polarization techniques. The results showed that Silene marmarica inhibited the corrosion of steel in $0.5 \mathrm{M} \mathrm{H}_{2} \mathrm{SO}_{4}$ and the presence of iodide ions produced a synergistic effect. The adsorption behavior of Silene marmarica in absence and presence of iodide ions was formed to fit both Langmuir isotherm and the Kinetic-thermodynamic model.

The inhibition efficiencies of Kraft lignin (KL) and Soda lignin (SL) of the corrosion of mild steel in $3.5 \% \mathrm{NaCl}$ solution at pHs 6 and 8 were studied by E. Akbarzadeh et al. (2011) [42] using weight loss, electrochemical techniques and surface analysis for 50$800 \mathrm{ppm}$ inhibitor concentration at $25^{\circ} \mathrm{C}$. Both $\mathrm{KL}$ and SL extracts acted as good inhibitors, the KL gave maximum inhibition efficiency of $95 \%$ and $92 \%$ for $\mathrm{pH} 6$ and $\mathrm{pH} 8$ respectively, whereas SL gave 97 and 95\% inhibition efficiency for $\mathrm{pH} 6$ and 8, respectively at $800 \mathrm{ppm}$ of inhibitor concentration.

M. Sangeetha et al. (2011) [43] studied the inhibition characteristics of Phyllanthus Amarus extract (PAE)- $\mathrm{Zn}^{2+}$ system for controlling corrosion of carbon steel in aqueous solution containing $60 \mathrm{ppm} \mathrm{Cl}^{-}$ion using weight loss method, the results indicated that the formulation containing of $2 \mathrm{ml}$ of PAE and $25 \mathrm{ppm} \mathrm{Zn}^{2+}$ has $98 \%$ inhibition efficiency. Polarization study indicated that this system functions as mixed-type inhibitor, AC impedance spectra reveal that a protective film is formed on the steel surface, and FTIR spectra indicated that the protective film consists of $\mathrm{Fe}^{2+}$-Phyllanthus complex.

D.E. Abd-El-khalek et al. (2012) [44] investigated the aqueous extract of Nicotiana leaves as corrosion inhibitor of steel in acidic and neutral chloride solutions using potentiodynamic polarization and electrochemical impedance spectroscopy techniques. The extract was found to be more effective in controlling corrosion of steel in acidic solution than in neutral one.

D. Asra Awizar et al. (2013) [45] studied the corrosion inhibition efficiency of nanosilicate extracted from rice husk ash (RHA), particle size in the range 10-20 nm for carbon steel in distilled water using potentiodynamic polarization and weight loss measurements, the inhibition efficiency of nano-silicate attained 99\% after 6 hours exposure. 
V. Johnsirani et al. (2013) [46] studied the efficiency of the aqueous extract of Eclipta alba Leaves in controlling the corrosion of carbon steel in sea water using the weight loss method. The results indicated that the formulation consisting of $6 \mathrm{ml}$ extract and $25 \mathrm{ml}$ of $\mathrm{Zn}^{2+}$ has $92 \%$ inhibition efficiency in controlling corrosion of carbon steel in sea water. Polarization study showed that above system functions as a mixed type inhibitor. AC impedance spectra indicated that a protective film is formed on the metal surface which was analyzed by FTIR spectra and AFM analysis.

H. Wang et al. (2014) [47] studied scale and corrosion performance of tobacco rob as extract in artificial sea water using potentiodynamic polarization and static tests. The results showed that the extract had good scale and corrosion inhibition properties for carbon steel in artificial sea water.

M.A. Deyab (2016) [48] investigated the inhibition effect of Seaweed extract on the corrosion of mild steel in saline formation water by weight loss, polarization and EIS techniques. Polarization results indicated that Seaweed extract retards the anodic reaction. The inhibition efficiency increases with the increase in Seaweed extract concentration but decreases with the rise in temperature.

P. Parthipan et al. (2017) [49] studied the inhibition of the corrosion of carbon steel API 51X by neem extract in presence of different bacterial strains (Bacillus subtilis A1, Streptomyces parvus B7, Pseudomonas stutzeri NA3 and Acinetobacter baumannii MN3) using weight loss method, potentiodynamic polarization and electrochemical impedance spectroscopy techniques and surface techniques; Fourier transform infrared spectroscopy (FT-IR). The results indicated that neem extract consists of azadirachtin and other phytochemical compound which was play a key role in control of bacterial biofilm on metal surface and inhibit the corrosion process.

M.A. Deyab et al. (2017) [50] investigated the anti-corrosion properties of lemongrass (Cymbopogon citratus) extract (LGE) for carbon steel in produced oilfield water using weight loss method and electrochemical impedance spectroscopy technique. They found that the extract serve as an effective corrosion inhibitor for carbon steel via adsorption of its constituents on the steel surface.

K. Nasr et al. (2018) [51] investigated the inhibition performance of the aqueous extract of Matricaria recutita chamomile on the corrosion of S235JR steel in $0.5 \mathrm{M} \mathrm{NaCl}$ using electrochemical impedance spectroscopy (EIS) and polarization measurements. They found that its inhibition efficiency increases with increasing the concentration of the extract and an increase in the immersion time. The optimum inhibition efficiency of chamomile extract, $98.9 \%$, was achieved for 5235JR steel when immersed in $15 \% \mathrm{v} / \mathrm{v}$ of the extract for 2 hours.

V. Grudić et al. (2018) [52] studied the inhibition of the corrosion of X52 5L carbon steel in $0.5 \mathrm{M} \mathrm{NaCl}$ solution by propolis extract using the potentiodynamic polarization method. The results indicated that, the propolis extract acts as anodic type inhibitor whose efficiency increase with increasing temperature and with stirring of the solution.

F.E.T. Heakal et al. (2018) [53] studied the corrosion inhibition of the carbon steel by cornflower (Centaurea cyanus) extract (CFE) in harsh saline formation water using weight 
loss method, potentiodynamic polarization and EIS techniques. The polarization results indicated that, this extract acts as mixed-type inhibitor with protection efficiency of $69 \%$ at extract addition of $10 \mathrm{ppm}$.

Z. Mohammadi et al. (2018) [54] studied the inhibition efficiency of Mazuj gall extract in simulated cooling water. Potentiodynamic polarization, electrochemical impedance spectroscopy, gravimetric measurements and ultraviolet-visible spectroscopy were used to investigate the corrosion inhibition efficiency and mechanism. The scale inhibition efficiency of the extract was evaluated using static beaker testing and scanning electron microscopy. The results indicated that, $1000 \mathrm{rpm} \mathrm{Mazuj} \mathrm{gall} \mathrm{extract} \mathrm{provided} \mathrm{corrosion}$ inhibition efficiency of $94.3 \%$ and scale inhibition efficiency of $97.2 \%$.

S. Devikala et al. (2019) [55] studied the inhibition properties of the extract of Asafoetida for the corrosion of mild steel in $3.5 \% \mathrm{NaCl}$ solution using the potentiodynamic polarization and EIS techniques. The formation of protective layer on the surface of the metal was confirmed by FT-IR, XRD and SEM.

The role of Juglans regia green fruit shell (JRS) extract as corrosion inhibitor for mild steel in 3.5\% $\mathrm{NaCl}$ solution was studied by S.A. Haddadi et al. (2019) [56] using potentiodynamic polarization, EIS and electrochemical current noise analysis. The inhibition efficiency of 1000 ppm JRS extract was $94 \%$ for steel plate in $3.5 \% \mathrm{NaCl}$ solution. The EIS results indicated that, the inhibition efficiency increases with the immersion time progress up to 48 hour.

Z. Sanaei et al. (2019) [57] studied the synergistic inhibition capacity of Chicory leaves extract (CLE) combined with $\mathrm{Zn}^{2+}$ ion against mild steel corrosion in $\mathrm{Cl}^{-}$ion solutions. The results from electrochemical techniques indicated that the effective synergic corrosion inhibition impact of the CLE (100 ppm) in presence of $\mathrm{Zn}^{2+}(100 \mathrm{ppm})$ with inhibition power of $96 \%$.

M.T. majd et al. (2019) [58] investigated the synergistic impact between the Eucalyptus leaves extract (ELE)and $\mathrm{Zn}^{2+}$ cation for inhibition of the corrosion of the mild steel in $\mathrm{NaCl}$ solution. Surface study was examined by ultra-violate visible analysis (UV-Vis), scanning electron microscope (SEM), energy dispersive spectroscopy (EDS), atomic force microscope (AFM), grazing incidence X-ray diffraction (GIXRD), Fourier transmission infrared (FTIR) spectroscopy and contact angle (CA) measurements. The corrosion rate measurements of the mild steel samples were carried out by electrochemical techniques in $\mathrm{NaCl}$ solution containing different ratios of $\mathrm{EIE}$ and $\mathrm{Zn}^{2+}$ ions. The results indicated that $200 \mathrm{ppm} \mathrm{ELE}+600 \mathrm{ppm} \mathrm{Zn}^{2+}$ had the highest inhibition efficiency (90\%) and synergistic impact.

M.T. majd et al. (2019) [59] studied inhibition system of Persian Echium amoenum (PEA) and zinc metal for mild steel protection in $3.5 \% \mathrm{NaCl}$ solution. The functional groups and complexes is in the structure of PEA and PEA: Zn containing solution were investigated by UV-Vis analysis, however, The composition and morphology tests of surface films were carried out by Fourier transform infrared spectroscopy (FT-IR). Scanning electron microscope (SEM), atomic force microscope (AFM), nuclear magnetic resonance 
spectroscopy (NMR), grazing incident $\mathrm{x}$-ray diffraction (GIXRD) analysis and static contact angle (CA) measurements. The electrochemical impedance spectroscopy (EIS) and potentiodynamic spectroscopy (PDs) were used to measure the corrosion rate of mild steel samples in $\mathrm{NaCl}$ solution containing different ratios of PEA: $\mathrm{Zn}$ system, the results indicated that, the 200 ppm PEA + 600 ppm Zn sample has the highest efficiency (95\%).

M.T. majd et al. (2020) [60] investigated the inhibition characterization of the extract of Esfand seed (ESE) for the corrosion of low carbon steel in a saline solution. Surface and electrochemical analysis were carried out by ultraviolet-visible spectroscopy (UV-Vis), Fourier transform infrared spectroscopy (FT-IR), grazing incident x-ray diffraction (GIXRD) analysis, field emission scanning electron microscope (FE-SEM), energy dispersive spectroscopy (EDS), atomic force microscope (AFM), electrochemical impedance spectroscopy (EIS) and potentiodynamic methods. The electrochemical studies established the efficiencies of zinc cation addition to the extract containing solute on its inhibition efficiency. The inhibition efficiency of the low carbon steel samples was $98.8 \%$ after 265 hour immersion inhibited by 300 ppm ESE + 700 ppm Zn.

\section{II.2. Plant extracts as inhibitors for corrosion of aluminium and its alloys}

Due to the combination of the following properties, light weight (density $=2.7 \mathrm{~g} \cdot \mathrm{cm}^{-3}$ ), mechanical strength, good corrosion resistance and nontoxic quality, aluminium and its alloys have a great number of engineering application [61, 62]. Aluminium and its alloys are the popular choice for many critical applications in the field of aerospace, food industry, construction, heat exchange and electrical transmission. In many environments a naturally generated, protective oxide film provide aluminium with corrosion immunity. This film is amphoteric and can be dissolve when it is exposed to either acid ( $\mathrm{pH}$ less than 5) or alkali (pH greater than 9 media. Aluminium and its alloys, due to their wide applications come in contact with acids or bases during pickling, descaling and electrochemical etching [63]. The corrosion resistance of aluminium and its alloys using inhibitors has been investigated in great variety of environments.

\section{II.2.a. Plant extracts as inhibitors for corrosion of aluminium and its alloys in acid media}

The inhibitive effect of Hibiscus subdariffa (karkade) extract as green corrosion inhibitor for aluminium and zinc in $2 \mathrm{~N} \mathrm{HCl}$ solution were studied by El-Hosary et al. (1972) [64]. They studied also (1993) [65] the inhibition of corrosion of aluminium, copper, and steel by Molasses.

G.O. Avwiri et al. (2003) [66] studied the action of Vernonia amygdalina (biter leaf) on the acidic corrosion of 25 and 3RS aluminium alloys using weight loss method. The results showed he highest inhibition efficiency of $49.5 \%$ for $0.1 \mathrm{M} \mathrm{HCl}$ and $72.5 \%$ for $0.1 \mathrm{M}$ $\mathrm{HNO}_{3}$ respectively.

The inhibitive action of the mucilage extracted from modified stems of prickly pears toward acid corrosion of aluminium was investigated by A.Y. El-Etre (2003) [67] using weight loss, thermometry, hydrogen gas evolution and polarization techniques. It was found 
that the extract act as a good inhibitor for corrosion of aluminium in $2 \mathrm{M} \mathrm{HCl}$ solution and its inhibition action was discussed in view of Langmuir adsorption isotherm. It was found also that the Opuntia extract provides a good protection to aluminium against pitting corrosion in chloride ion containing solution.

The leaf extracts of Chlomolaena odorata L. were studied for inhibition of the corrosion of aluminium in $2 \mathrm{M} \mathrm{HCl}$ by I.B. Obot et al. (2010) [68] using gasometric and thermometric techniques. Results indicated that this extract functioned as an excellent inhibitor for corrosion of aluminium in the acidic solutions. The adsorption of the components of the extract on the aluminium surface obeys Langmuir isotherm.

O.K. Abiola et al. (2010) [69] studied the inhibitive effect of Cocos nucifera L. for the corrosion of aluminium in $0.5 \mathrm{M} \mathrm{HCl}$ solution using chemical technique. The results showed that this extract showed significant inhibition for corrosion of aluminium with $93 \%$ efficiency at highest concentration. The inhibition action was attributed to the adsorption of the extract components molecules on the aluminium surface following Langmuir adsorption isotherm.

The corrosion inhibition effect of Aningeria robusta extract for aluminium in $2 \mathrm{M} \mathrm{HCl}$ solution was investigated by I.B. Obot et al. (2011) [70] using hydrogen evolution method at 30 and $60^{\circ} \mathrm{C}$. Inhibition efficiency of the extract increased with an increase of the Aningeria robusta extract and the inhibition efficiency synergistically increased on addition of potassium iodide.

The inhibitive effect of leaf extract of Euphorbia hirta on aluminium corrosion in $\mathrm{HCl}$ and $\mathrm{NaOH}$ solutions were studied by L.A. Nnanna et al. (2011) [71] using weight loss method at 30 and $60^{\circ} \mathrm{C}$. This extract is more effective for corrosion of aluminium in the acidic medium than in the alkaline medium. The adsorption characteristics of the leaf extract were described by Langmuir isotherm.

M.M. Fares et al. (2012) [72] studied the inhibition behavior of pectin for corrosion of aluminium in hydrochloric acid solution. The inhibition efficiency first increased linearly up to $2.0 \mathrm{~g} / \mathrm{L}$ - and then it continues steady exponential increase until it reached plateau. The maximum inhibition efficiency obtained at $10^{\circ} \mathrm{C}$ using pectin concentration $=8.0 \mathrm{~g} / \mathrm{L}$ was $=91 \%$, whereas at $40^{\circ} \mathrm{C}$ it severally declined to $31 \%$. Adsorption of pectin macromolecule on aluminium surface demonstrated proper Langmuir isotherm fit.

X. Li et al. (2012) [73] studied the inhibitive effect of Dendrocalamus brandisii extract on the corrosion of aluminium in $\mathrm{HCl}$ and $\mathrm{H}_{3} \mathrm{PO}_{4}$ solution using weight loss, potentiodynamic polarization and electrochemical impedance spectroscopy method. The results showed that it is a good inhibitor in $1 \mathrm{M} \mathrm{HCl}$ solution while a moderate inhibitor in $\mathrm{H}_{3} \mathrm{PO}_{4}$. It acts as cathodic inhibitor in $\mathrm{HCl}$ solution, while it acts as mixed-type inhibitor in $\mathrm{H}_{3} \mathrm{PO}_{4}$.

S. Deng et al. (2012) [74] studied the inhibitive effect of Jasminum nudiflorum Lindl. leaves extract on the corrosion of aluminium in $\mathrm{HCl}$ solution using weight loss, potentiodynamic polarization curves, electrochemical impedance spectroscopy and scanning electron microscope methods. The results indicated that this extract acts as a good inhibitor 
for aluminium corrosion in $1 \mathrm{M} \mathrm{HCl}$, its adsorption obeys Langmuir adsorption isotherm and acts as cathodic type inhibitor.

A.I. Ali et al. (2012) [75] studied the inhibition of aluminium corrosion in $2 \mathrm{M} \mathrm{HCl}$ by black mulberry (Morus nigra L.) using weight loss, electrochemical polarization technique and hydrogen evolution measurements. Black mulberry extract acts as good inhibitor for aluminium corrosion in the acid solution. The inhibitive action of this extract was discussed in view of the adsorption of its components on the aluminium surface.

The effect of Commiphora pedunculata gum on the corrosion of aluminium alloy AA 3001 in $\mathrm{HCl}$ solution was studied by P.O. Ameh et al. (2014) [76] using gravimetric and thermometric methods. The results indicated that this gum is a good adsorption inhibitor for the corrosion of aluminium in $\mathrm{HCl}$ solution.

The effect of beetroot (betanin) extract on the corrosion inhibition of aluminium in aqueous solution at $\mathrm{pH} 3$ has been investigated by A. Nithya et al. (2015) [77] using mass loss method, potentiodynamic polarization and electrochemical impedance spectroscopy techniques. The results indicated that betanin extract is a good green inhibitor for aluminium in an aqueous solution at $\mathrm{pH} 3$. It acts as a mixed-type inhibitor and maximum inhibition efficiency $98 \%$ was obtained at $2 \mathrm{ml}$ extract.

M. Akin et al. (2015) [78] studied the inhibitive action of Juglans regia L. extract as green inhibitor for stainless steel and aluminium in $1 \mathrm{M} \mathrm{HCl}$ using weight loss method, potentiodynamic polarization and electrochemical impedance spectroscopy techniques. The inhibition efficiency was found $88.8 \%$ for aluminium. The effect of immersion time (28 hours) was discussed and adsorption mechanism was fitted with Langmuir isotherm.

The inhibition behavior of Thymus algeriensis extract on the corrosion of $2024 \mathrm{Al}$ alloy was investigated by A. Khadraoui et al. (2016) [79] using weight loss, gasometry and electrochemical impedance spectroscopy techniques. The inhibition efficiency of the Thymus algeriensis extract is $78.7 \%$ at $0.75 \mathrm{~g} / \mathrm{L}$. The inhibitive effect of the extract was discussed in view of adsorption of its components on the aluminium surface following Langmuir isotherm.

Y.C. Sharma et al. (2016) [80] studied the corrosion inhibition of ethanol extract of Psidium guajava seeds for aluminium in $0.5 \mathrm{M} \mathrm{HCl}$ using weight loss, FTIR spectroscopy and SEM analysis techniques. The results showed that, this extract performed well as inhibitor for the corrosion of aluminium in hydrochloric acid solution and the inhibition mechanism was by adsorption process through Langmuir isotherm.

O.U. Abakedi et al. (2016) [81] studied the inhibition effect of the extract of Maesobatrya barteri root extract on the corrosion of aluminium in hydrochloric acid solution using gasometric and thermometric methods. The adsorption of the components of the extract on the aluminium surface obeyed Langmuir adsorption isotherm and the adsorption process was physical in nature.

The inhibitive effect of the as-synthesized baicalin derivatives was investigated by Y.T. Du et al. (2017) [82] as ecofriendly green inhibitor on the corrosion of aluminium in $1 \mathrm{M} \mathrm{HCl}$ solution using weight loss and electrochemical techniques. The results indicated 
that the bacalin derivatives exhibited excellent performance as inhibitor for aluminium corrosion and acted as mixed-type inhibitors. The maximum inhibition efficiency at $25^{\circ} \mathrm{C}$ is $95 \%$ at $0.9 \mathrm{~g} / \mathrm{L}$. The experimental results of adsorption obeys Langmuir adsorption isotherm.

Polygonatum odoratum extract was studied as corrosion inhibitor for aluminium in $1 \mathrm{M}$ $\mathrm{HCl}$ by M. Prabakaran et al. (2018) [83] using weight loss, potentiodynamic polarization, electrochemical impedance spectroscopy and scanning electron microscope techniques. This extract acts as mixed-type inhibitor.

The inhibition of the corrosion of aluminium in $0.5 \mathrm{M} \mathrm{HCl}$ solution by Areca palm leaves extract was studied by N. Raghavendra et al. (2018) [84] using weight loss, AC impedance spectroscopy, potentiodynamic polarization and scanning electron microscopy methods. The adsorption of molecules of the components of the extract on the aluminium surface fitted Langmuir adsorption isotherm.

S. Bashir et al. (2019) [85] studied the corrosion inhibition behavior of Shatavari (Asparagus racemosus) for aluminium in acid medium using weight loss, quantum chemical analysis and scanning electron microscopy. The results indicated that $4000 \mathrm{ppm}$ concentration of the extract give inhibition efficiency of $72.28 \%$. The experimental results obeys Langmuir adsorption isotherm.

\section{II.2.b. Plant extracts as inhibitors for corrosion of aluminium and its alloys in neutral and alkaline media}

The inhibitive action of the extract of the leaves of Sansevieria trifasciata on aluminium corrosion in $2 \mathrm{M} \mathrm{HCl}$ and $2 \mathrm{M} \mathrm{KOH}$ solutions were studied by E.E. Oguzie (2007) [86] using gasometric technique. The results indicated that this extract functioned as a good inhibitor in both environments. Synergistic effects increased the inhibition efficiency in the presence of halide ions. A mechanism of physical adsorption was proposed of the inhibition behavior and the adsorption process obeyed Freundlich isotherm.

A.M. Abdel-Gaber et al. (2008) [87] studied the inhibition of the aluminium corrosion in $2 \mathrm{M} \mathrm{NaOH}$ by damsisa (Ambrosia maritime L.) extract using chemical and electrochemical techniques. The extract behaved as mixed-type inhibitor. The results indicated that the damsisa extract could serve as an effective inhibitor for corrosion of aluminium in alkaline solutions. The impedance results verified the remarkable stability of extracts during storage up to 35 days.

O.K. Abiola et al. (2009) [88] studied the corrosion inhibition behavior of Gossypium hirsutum L. leave and seed extracts for aluminium in $2 \mathrm{M} \mathrm{NaOH}$ solution using chemical technique. The results indicated that the leave extract was more efficient than seed extract. The leave extract gave $97 \%$ inhibition efficiency while the seed extract gave $94 \%$ at the highest concentration.

R. Rosliza et al. (2010) [89] examined the use of Tapioca starch for improvement of corrosion resistance of AA 6061 alloy in sea water using gasometry, potentiodynamic polarization, linear polarization resistance and electrochemical impedance spectroscopy measurements. The results indicated that the presence of tapioca starch in the sea water 
decrease the corrosion rate, corrosion current density, double layer capacitance and increase the value of polarization resistance. The Langmuir adsorption isotherm fits well the experimental data.

J. Halambek et al. (2010) [90] studied the effect of natural oil extracted from Lavandula angustifolia $\mathrm{L}$. oil as corrosion inhibitor for $\mathrm{Al}-3 \mathrm{Mg}$ in $3.5 \% \mathrm{NaCl}$ solution using weight loss, polarization measurements and scanning electron microscope. It was found that this extract protect aluminium alloy against pitting corrosion in $\mathrm{NaCl}$ solution.

The corrosion behavior of aluminium in $0.5 \mathrm{M} \mathrm{NaOH}$ in presence of Azwain (Trachyspermum copticum) seed extract by S. Ambrish et al. (2012) [91] using weight loss and electrochemical techniques was studied. The experimental results indicated that the inhibition efficiency increases with increasing the extract concentration and reached $94 \%$ at $5000 \mathrm{ppm}$. Tafel polarization results indicated that the extract act as a mixed-type inhibitor. The adsorption of the molecules of the extract on the surface of aluminium followed Langmuir adsorption isotherm.

The inhibition characteristics of the aqueous extract of fruits of Terminalia chebula (TCE) was studied by D. Prabhu et al. (2013) [92] for the corrosion of 6063 aluminium alloy in $0.5 \mathrm{M} \mathrm{NaOH}$ solution using weight loss and potentiodynamic methods. Inhibition efficiency increased with concentration of the extract. The adsorption of the TCE extract on the metal surface obeyed the Langmuir adsorption isotherm, acted as mixed-type inhibitor and followed physical adsorption on the surface of the metal.

E.M. Nawafleh et al. (2013) [93] studied the inhibition efficiency of the extract of Salvia judaica on corrosion of aluminium in $1 \mathrm{M} \mathrm{NaOH}$ solution using weight loss method. Results indicated that the extract act as corrosion inhibitor for the corrosion of aluminium in $1 \mathrm{M} \mathrm{NaOH}$. The adsorption of the extract on the aluminium surface obeyed Langmuir adsorption isotherm.

S. Geetha et al. (2013) [94] investigated the influence of the extract of Vitex negundo leaves on the corrosion of aluminium in $1 \mathrm{M} \mathrm{NaOH}$ using chemical and electrochemical methods. It was found that this extract act as corrosion inhibitor for alkaline corrosion of aluminium through a Langmuir adsorption isotherm.

J. Halambek et al. (2013) [95] investigated the effect of 30\% v/v ethanolic solution of Laurus nobilis L. oil on the corrosion of aluminium and AA5754 aluminium alloy in 3\% $\mathrm{NaCl}$ solution using weight loss method, potentiodynamic polarization and linear polarization resistance techniques. The results indicated that addition of 10 to $50 \mathrm{ppm}$ oil concentration leads to the inhibition of the corrosion of aluminium and its alloy in the tested media.

M.K. Irshedat et al. (2013) [96] studied the effect of the extract of Lupinus varius L. on the corrosion of aluminium using weight loss method. This extract inhibited the alkaline corrosion of in aluminium $1 \mathrm{M} \mathrm{NaOH}$ solution and the inhibition efficiency of the extract increased with increasing the concentration of the extract and decreased with increasing temperature. The adsorption of the inhibition molecules on aluminium surface obeyed Langmuir adsorption isotherm. 
The inhibition effect of Sinapis alba (SA) extract was examined for corrosion of aluminium in 1.0 M NaOH solution by T.T. Bataineh (2014) [97] using weight loss method, electrochemical polarization method and the surface morphology was analyzed by scanning electron microscopy. The inhibition efficiency increases with the extract concentration and reaches $79.98 \%$ with highest extract concentration at $50^{\circ} \mathrm{C}$. This adsorption of the extract on aluminium surface obeyed Langmuir adsorption isotherm. Electrochemical polarization studies showed that the Sinapis alba extract acts as mixed-type inhibitor.

H.A. Fetouh et al. (2014) [98] studied the effect of aqueous extract of Damsisa, Lupine and Halfa-bar on the corrosion of 7075-T6 aluminium alloy in $0.5 \mathrm{M} \mathrm{NaCl}$ solution using electrochemical impedance spectroscopy and potentiodynamic polarization techniques. The results indicated that the three extracts act as cathodic-type inhibitors for the corrosion of aluminium alloy in the $\mathrm{NaCl}$ solution. Theoretical fitting of Langmuir, Flory Huggins adsorption isotherms and the kinetic-thermodynamic model were tested to clarify the adsorption mechanism.

H. Gerengi et al. (2015) [99] investigated the Mimosa extract as green corrosion inhibitor for AA6060 aluminium alloy in acid solution using electrochemical impedance spectroscopy (EIS) and dynamic electrochemical impedance spectroscopy (DEIS). The results indicated that this extract inhibited the corrosion of the aluminium alloy with $45 \%$ efficiency at $2750 \mathrm{ppm}$.

The inhibition effect of the aqueous extract of Alstonia Scholaris ark was studied by N. Chaubey et al. (2016) [100] for the corrosion of aluminium alloy in $1 \mathrm{M} \mathrm{NaOH}$ solution using gravimetric, potentiodynamic polarization, linear polarization resistance and electrochemical impedance spectroscopy techniques. The results showed that, this extract act as good inhibitor for corrosion of aluminium in $1 \mathrm{M} \mathrm{NaOH}$ solution with maximum efficiency of 92.6 at $20 \mathrm{~g} / \mathrm{L}$. The experimental results was found to fit the Langmuir adsorption isotherm.

The aqueous extract of Neolamarckia cadamba was investigated by N. Chaubey et al. (2015) [101] as corrosion inhibitor for aluminium alloy in $1 \mathrm{M} \mathrm{NaOH}$ using weight loss and polarization resistance, Tafel polarization and electrochemical impedance spectroscopy techniques. The results indicated that, this extract inhibited the corrosion of aluminium in $\mathrm{NaOH}$ solution with efficiency of $87 \%$ at $0.6 \mathrm{~g} / \mathrm{L}$ and it acts as mixed-type inhibitor.

N. Chaubey (2015) [102] studied the inhibition of performance of the peels extracts of each of Pisum sativum (PS), Solanum tuberosum (ST) and Citrus reticulata (CR) on the corrosion of aluminium alloy in $1 \mathrm{M} \mathrm{NaOH}$ solution using weight loss, electrochemical impedance spectroscopy, linear polarization and potentiodynamic polarization techniques. The three peel extracts showed good performance, PS exhibited maximum inhibition efficiency of $94.5 \%$ at $1.5 \mathrm{~g} / \mathrm{L}$ and behaved as mixed-type inhibitor.

The inhibitive effect of Cleome droserifolia leaves extract on the corrosion of aluminium metal in $1 \mathrm{M} \mathrm{NaOH}$ solution was studied by M.M.A. Qudah (2015) [103] using the weight loss method at different temperatures. The surface morphology of aluminium metal was analyzed using scanning electron microscope. The extract of $14 \mathrm{~g} / \mathrm{L}$ at $35^{\circ} \mathrm{C}$ gave 
the highest inhibition efficiency of $78.6 \%$ and its adsorption on the aluminium surface obeyed Temkin adsorption isotherm.

The inhibition characteristics of the plants leaves extract of each of Cannabis sativa (CS), Rauvolfia serpentina (RS), Cymbopogon citratus (CC), Annona squamosa (AS) and Adhatoda vasica (AV) was studied by N. Chaubey et al. (2017) [104] as inhibitors for corrosion of aluminium alloy in alkaline media using gravimetric, electrochemical impedance spectroscopy, potentiodynamic polarization and linear polarization resistance techniques. The extracts showed maximum inhibition efficiency $97 \%$ at $0.2 \mathrm{~g} / \mathrm{L}$ and act as mixed-type inhibitors.

The effect of Kalmegh leaf extract on the corrosion of aluminium in $1 \mathrm{M} \mathrm{NaOH}$ solution was studied by N. Chaubey (2017) [105] using electrochemical impedance spectroscopy and potentiodynamic polarization techniques. The results indicated that the inhibition efficiency of this extract increased with increasing of its concentration and maximum inhibition efficiency obtained was $82.45 \%$ at higher concentration. The adsorption of the inhibitor on aluminium surface obeyed Langmuir adsorption isotherm and it acts as mixed-type inhibitor.

The effect of stem bark extracts of three trees namely Moringa oleifera (MO), Terminalia arjuna (TA) and Mangifera indica (MI) on the corrosion of aluminium alloy in $1 \mathrm{M} \mathrm{NaOH}$ solution were studied by N. Chaubey et al. (2017) [106] using gravimetric, potentiodynamic polarization and electrochemical impedance spectroscopy measurements. The results indicated that the three extracts act as mixed-type inhibitors and obeyed Langmuir adsorption isotherm. MO extract exhibited the maximum inhibition efficiency of $85.3 \%$ at $0.6 \mathrm{~g} / \mathrm{L}$.

H. Elgahawi et al. (2017) [107] studied the inhibitive effect of Limum usitaissimum (ELUS) seeds extract on the corrosion of aluminium alloy AA 2024 in 3.5\% NaCl solution using potentiodynamic polarization and electrochemical impedance spectroscopy and electrochemical noise measurement techniques. Results indicated that the extract of ELUS effectively inhibited the corrosion of aluminium alloy with efficiently range from 65 to $82 \%$ for the corresponding extract concentration from 80 to $1200 \mathrm{ppm}$. Potentiodynamic polarization results showed that ELUS act as cathodic-type inhibitor, however, the electrochemical impedance spectroscopy results indicated that the corrosion process was governed by charge transfer.

N. Raghavendra et al. (2018) [108] studied the effect of green color Arecanut husk extract as inhibitor for corrosion of aluminium in both $0.5 \mathrm{M} \mathrm{HCl}$ and $0.1 \mathrm{M} \mathrm{NaOH}$ solutions using weight loss method and potentiodynamic polarization technique. The influence of temperature and time on adsorption of the extract constituent on the surface of aluminium has been studied. The results indicated that the introduction of the extract appreciably decreased the rate of aluminium corrosion.

Konjac glucomanan was extracted from commercial product and studied by K. Zhang et al. (2018) [109] as a green corrosion inhibitor for AA5052 aluminium alloy in 3\% $\mathrm{NaCl}$ solution using high performance gel permeation chromatography (GPC), thermo-gravimetric analysis (TGA), Fourier transform infrared (FT-IR) spectra, electrochemical measurements 
and surface characterization techniques. Potentiodynamic polarization results indicated that, konjac glucomanan behaves as a mixed-type inhibitor, moreover, electrochemical noise (EN) indicated that the growth and propagation stages of the pitting corrosion germinating on the metal surface are packed by polysaccharide additives.

The corrosion inhibition behavior of bee products for aluminium alloy in alkaline media was studied by J. Ryl (2019) [110] using potentiodynamic polarization and impedance techniques. Various bee products were found to be efficient corrosion inhibitors of aluminium in different environments, in particular, bee pollen was found to be highly effective in alkaline media. The highest inhibition efficiency exceeding $90 \%$ at $10 \mathrm{~g} / \mathrm{L}$ was recorded for the water-ethanol extract.

Different plant parts extracts of Tribulus terrestris were employed against aluminium corrosion in basic media by P. Rathi et al. (2019) [111] using weight loss, thermometric method, potentiodynamic polarization and electrochemical impedance spectroscopy techniques. The surface analysis was carried out by Fourier transform infrared spectroscopy and scanning electron microscopy. The results showed an inhibition efficiency greater than $70 \%$ with leaves extract in $0.5 \mathrm{M} \mathrm{NaOH}$ solution.

\section{II.3. Plant extracts as inhibitors for corrosion of copper and its alloys}

Copper is one of the most important metals in industry because of its high electrical and thermal conductivities, so it is used in many industrial applications such as conductors in electrical power lines, pipelines, heat conductors of heat exchangers, sea water desalination and shipbuilding [112-115]. Copper metal suffer different forms of corrosion depending on the environment, so one of the major challenges in copper applications is controlling the copper corrosion.

The efficiency of acid extract of Azadirachta indica seed as corrosion inhibitor for mild copper metal in 1, 2, $3 \mathrm{~N} \mathrm{HNO}_{3}$ solution was studied by T.V. Sangeetha et al. (2011) [116] using weight loss method. The results indicated that Azadirachta indica seed act as good corrosion inhibitor for copper in nitric acid having efficiency of $95 \%$ at $1 \%$ inhibitor concentration in different time duration.

The inhibitive effect of Mangure tannin as green inhibitor for the corrosion of copper in $0.5 \mathrm{M} \mathrm{HCl}$ solution was studied by A.M. Shah (2013) [117] using weight loss, potentiodynamic polarization, electrochemical impedance spectroscopy, scanning electron microscope, with energy dispersive x-ray (EDX), atomic absorption spectroscopy (AAS) and ion chromatography (IC). The highest inhibition efficiency achieved $82 \%$ at $3 \mathrm{~g} / \mathrm{L}$. The results indicated that Mangrove tannin act as cathodic inhibitor and its adsorption process obeys Langmuir isotherm.

Cannabis plant extract was tested as green corrosion inhibitor in $0.5 \mathrm{M} \mathrm{H}_{2} \mathrm{SO}_{4}$ solution by B.A. Abd-El-Nabey et al. (2013) [118] using weight loss, potentiodynamic polarization, electrochemical impedance spectroscopy and optical micrograph techniques. The results indicated that the dissolution process of copper is controlled by diffusion and cannabis 
extract act as cathodic inhibitor. Langmuir, Flory-Huggins and Kinetic-thermodynamic model were tested to clarify the nature of adsorption.

The inhibitive action of caffeine isolated from black tea on corrosion of copper in $0.5 \mathrm{M}$ $\mathrm{NaCl}$ solution was studied by S. Gudić et al. (2014) [119] using potentiodynamic polarization and electrochemical impedance spectroscopy techniques. The results showed that caffeine acted as an effective corrosion inhibitor for copper in $\mathrm{NaCl}$ solution with an inhibition efficiency up to $92 \%$. Polarization results indicated that caffeine act as cathodic type inhibitor by adsorption on the copper surface according to Langmuir isotherm.

Inhibition of the $\mathrm{Cu} 65 / \mathrm{Zn} 35$ brass corrosion in $0.1 \mathrm{~N} \mathrm{Na}_{2} \mathrm{SO}_{4}$ solution with $\mathrm{pH} 7$ and 4 by natural extract of Camellia sinensis was investigated by T. Ramde (2014) [120] using potentiodynamic polarization, electrochemical impedance spectroscopy and scanning electron microscope techniques. The results indicated that the extract is a very effective corrosion inhibitor for brass corrosion in both acidic and neutral media.

The corrosion inhibition effect of Calligonum comosum extract on copper in $2 \mathrm{M} \mathrm{HCl}$ solution has been investigated by M. Shabani-Nooshabadi et al. (2015) [121] using potentiodynamic polarization and electrochemical impedance spectroscopy techniques. The polarization studies showed that this extract act as mixed-type inhibitor and a maximum inhibition efficiency of $80.06 \%$ was obtained in $0.8 \mathrm{~g} / \mathrm{L}$ extract. The inhibitory action of the extract was discussed on the basis of Langmuir adsorption isotherm.

The inhibitive effect of alcoholic extract of Mimusops elengi leaves on copper corrosion in natural sea water was investigated by P. Deivanayagam (2015) [122] using weight loss measurements. The maximum inhibition efficiency was $86.84 \%$ after 120 hours immersion. The adsorption of inhibitor on the metal surface followed the chemical adsorption mechanism.

The inhibitive action of Alhagi Maurorum plant extract on the corrosion of copper in $0.5 \mathrm{M} \mathrm{H}_{2} \mathrm{SO}_{4}$ solution was studied by B.A. Abd-El-Nabey (2015) [123] using weight loss, potentiodynamic polarization and electrochemical impedance spectroscopy techniques. The results indicated that this extract act as a good cathodic-type inhibitor and its adsorption on the copper surface obey the isotherms of Langmuir, Flory-Huggins and Kineticthermodynamic model.

Olive leaf extract as a natural corrosion inhibitor for pure copper in $0.5 \mathrm{M} \mathrm{NaCl}$ solution was studied by C. Rahal (2016) [124] using potentiodynamic polarization and electrochemical impedance spectroscopy techniques. The highest inhibition efficiency was 90\% after 24 hours immersion. The electrochemical results indicated that this extract acted as cathodic-type inhibitor and hindering the reduction of dissolved oxygen.

Myrrh extract as a corrosion inhibitor for a copper-zinc alloy in $3.5 \mathrm{Wt} . \% \mathrm{NaCl}$ solution polluted by 16 ppm sulphide was studied by H.S. Gadow et al. (2017) [125] using weight loss method, electrochemical measurements, AFM, UV spectroscopy and FT-IR. The results indicted hat the inhibition efficiency of the extract increase with its concentration and reach $67 \%$ at $300 \mathrm{ppm}$ and $25^{\circ} \mathrm{C}$. Potentiodynamic results indicated that the extract act as mixedtype inhibitor and its adsorption at the alloy surface obey Langmuir isotherm. 
Capparis spinosa $\mathrm{L}$. extract was used as green inhibitor for copper corrosion in strong acid media by F. Wedian et al. (2017) [126] using weight loss and polarization measurements. The results indicated that this extract act as an efficient inhibitor for corrosion of copper in strong acid medium with maximum inhibition efficiency of $82.7 \%$ at $440 \mathrm{ppm}$ of the extract. The weight loss, potentiodynamic and chemical calculations were in a good agreement.

Ziziphus lotus (wild jujube) were tested as corrosion inhibitor for copper in sea water by R. Oukhrib et al. (2017) [127] using weight loss and polarization methods. The morphology of the copper surface was analyzed after immersion in inhibited and uninhibited electrolytes using the scanning electron microscope. The results revealed that the extract act as efficient inhibitor for the copper corrosion in sea water, the highest efficiency is $93 \%$ at $5 \mathrm{~g} / \mathrm{L}$.

The inhibitive action of natural Propolis on bronze corrosion in a weakly acidic solution containing $\mathrm{Na}_{2} \mathrm{SO}_{4}$ and $\mathrm{NaHCO}_{3}$ at pH 5 was studied by S. Varvara et al. (2017) [128] using potentiodynamic polarization, electrochemical impedance spectroscopy and scanning vibrating electrode technique measurements. The results showed that propolis act as effective inhibitor for corrosion of bronze with highest efficiency $98.9 \%$ at $100 \mathrm{ppm}$ after 12 hours immersion. The adsorption of the extract on bronze was found to follow Langmuir adsorption isotherm.

Berry leaves extract was examined as a green inhibitor for corrosion of copper in nitric acid solution by A.S. Fouda et al. (2018) [129] using weight loss, potentiodynamic polarization, electrochemical impedance spectroscopy and electrochemical frequency modulation techniques. The results indicated that this extract act as effective inhibitor for copper corrosion in $2 \mathrm{M} \mathrm{HNO}_{3}$ with inhibition efficiency of $90.1 \%$ at $300 \mathrm{ppm}$ and $45^{\circ} \mathrm{C}$. The adsorption of the extract on the copper surface was found to obey Temkin isotherm.

Aqueous and hydrolysis extracts of Olive leaf was studied as a green inhibitor for corrosion of copper in $0.5 \mathrm{M} \mathrm{NaCl}$ by P. Refat et al. (2020) [130] using electrochemical impedance spectroscopy and voltammetry techniques. The acid hydrolysis extract obtained at high temperature mainly contained hydroxyl tyrosol and clenolic acid and gave the highest inhibition efficiency of $95 \%$.

\section{II.4. Plant extracts as inhibitors for corrosion of zinc and its alloys}

Zinc is one of the most important nonferrous metals with numerous industrial applications and finds extensive use in metallic coating. Zinc corrodes in a solution with a $\mathrm{pH}$ lower than 6 and higher than 12.5, but within the range, the corrosion is very slow [131]. In aggressive environments, zinc metal undergoes corrosion, giving white colored rust $[132,133]$. The formation of the white rust on zinc surface is prevented by the application of chromate treatment [134]. Recent environmental regulation restrict the use of chromate solution and recommended its replacement with ecofriendly non-toxic and non-polluting substances.

The inhibitive action of Aloe vera leaves extract on the corrosion of zinc in $\mathrm{HCl}$ solution was studied by O.K. Abiola et al. (2010) [135] using weight loss technique. The extract 
inhibited the corrosion of zinc in $2 \mathrm{M} \mathrm{HCl}$. The adsorption of the inhibitor molecules on the zinc surface obeyed Langmuir isotherm. A first order kinetics relationship with respect to zinc was obtained with and without the extract.

The inhibitive action of Lubine, Hafabar and Damssisa on the corrosion of zinc in $0.5 \mathrm{M}$ $\mathrm{NaCl}$ solution were studied by B.A. Abd-El-Naby et al. (2012) [136] using potentiodynamic polarization and electrochemical impedance spectroscopy techniques. Potentiodynamic polarization results indicated that the three extracts act as mixed-type inhibitors and give good inhibition efficiency. Theoretical fitting of the isotherms of Langmuir, Flory-Huggins and kinetic thermodynamic model were tested to clarify the nature of adsorption.

Ethanolic extract of Mansoa alliacea was investigated as green inhibitor for corrosion of zinc in $3 \% \mathrm{NaCl}$ solution by F. Suedile et al. (2014) [137] using potentiodynamic polarization and electrochemical impedance spectroscopy techniques. The results indicated that the extract could serve as an effective inhibitor for the corrosion of zinc in $3 \% \mathrm{NaCl}$ solution. The extract gave $90 \%$ inhibition efficiency. Potentiodynamic polarization results indicated that the extract acts as mixed type inhibitor.

The inhibitive action of Allium cepa extract on the corrosion of zinc and carbon steel in $2 \mathrm{M} \mathrm{H}_{2} \mathrm{SO}_{4}$ was studied by A.J. Chinweuba (2014) [138] using weight loss method. The results indicated that this extract act as good inhibitor for corrosion of carbon steel and zinc in $2 \mathrm{M} \mathrm{H}_{2} \mathrm{SO}_{4}$ solution. The inhibition efficiency increases up to $97.7 \%$ for mild steel and $89.1 \%$ for zinc in $2 \mathrm{M} \mathrm{H}_{2} \mathrm{SO}_{4}$.

The inhibitive action and synergistic properties of extract of Moringa oleifera leaves on the corrosion of zinc in $\mathrm{HCl}$ solution was investigated by F.A. Ugebe et al. (2015) [139]. They studied the corrosion behavior of zinc immersed in $0.5 \mathrm{M}, 1.0 \mathrm{M}, 1.5 \mathrm{M}$ and $2.0 \mathrm{M}$ $\mathrm{HCl}$ solutions each containing varied concentrations of the extract $(0.1,0.3$ and $0.5 \mathrm{~g} / \mathrm{L})$ and halides $(0.1,0.3$ and $0.5 \mathrm{M}$ in each of $\mathrm{KCl}$ and $\mathrm{KI})$ for synergism using thermometric method. The data revealed that this extract is an efficient inhibitor for corrosion of zinc in acid solution due to its phytochemical, saponins, tannins, flavonoids, glycosides, carbohydrates, reducing sugars, terpenoids, steroids and alkaloids.

The alkaloid extract of Calendula officinalis (Pot Marigold) leaves was examined as corrosion inhibitor for corrosion of carbon steel, aluminium and zinc metals in $5 \mathrm{M} \mathrm{HNO}_{3}$ solution by B.U. Ugi et al. (2016) [140] using weight loss, potentiodynamic polarization and electrochemical impedance spectroscopy techniques. The weight loss results showed that the plant extract is an excellent corrosion inhibitor to all studied metals, the polarization results indicated that it acts as a mixed-type inhibitor.

Fenugreek seeds extract was investigated as a green corrosion inhibitor for zinc in $2 \mathrm{M}$ $\mathrm{H}_{2} \mathrm{SO}_{4}$ and $2 \mathrm{M} \mathrm{HCl}$ solutions by H.A. Al Lehaibi (2016) [141] using weight loss, electrochemical techniques, scanning electron microscope and x-ray photoelectron spectroscopy (XPS) analysis. The maximum inhibition efficiency values are $90.7 \%$ after 1 hour and $66.6 \%$ after 0.5 hour by $200 \mathrm{ppm}$ of the extract in $\mathrm{H}_{2} \mathrm{SO}_{4}$ and $\mathrm{HCl}$ solutions, respectively. 
The inhibitive action of the ethanolic extract of oil from Picralima nitida leaves for corrosion of zinc in $1.0 \mathrm{M} \mathrm{HCl}$ solution was studied by J.N.O. Ezeugo et al. (2017) [142] using weight loss and thermometry method. Results indicated that the inhibition efficiency of the extract reached $86.78 \%$ at $1.2 \mathrm{~g} / \mathrm{L}$ after 8 hours. The inhibitive action of the extract was discussed in view of Langmuir adsorption isotherm.

Solanum nigrum extract was investigated by A.S. Fouda et al. (2017) [143] as green inhibitor for corrosion of zinc in $3.5 \% \mathrm{NaCl}$ and $16 \mathrm{ppm} \mathrm{Na}_{2} \mathrm{~S}$ solution using weight loss, Tafel polarization and electrochemical impedance spectroscopy techniques. The results illustrated that this extract act as effective inhibitor for corrosion of zinc in $3.5 \% \mathrm{NaCl}$ and $16 \mathrm{ppm} \mathrm{Na}_{2} \mathrm{~S}$ solution. The inhibition efficiency reached $81.5 \%$ at $500 \mathrm{ppm}$ after 180 minutes immersion. The adsorption of the extract molecules on the zinc metal surface obeys Freundlich and Langmuir adsorption isotherm.

The inhibitive action of Fucoidan as green inhibitor for corrosion of zinc in sea water was investigated by C. Wang (2017) [144] using potentiodynamic polarization and electrochemical impedance spectroscopy techniques. Potentiodynamic polarization results showed that this extract acts as anodic type inhibitor. The corrosion inhibition of Fucoidan was confirmed by the scanning electron microscope and atomic force microscope. Langmuir adsorption isotherm was found the appropriate adsorption model.

Corrosion inhibition of zinc in $0.5 \mathrm{M} \mathrm{HCl}$ solution by Ailanthus altissima extract has been studied by A.S. Fouda (2018) [145] using weight loss, hydrogen evolution, potentiodynamic polarization, electrochemical impedance spectroscopy and electrochemical frequency modulation techniques. Results indicated that this extract exhibited high inhibition efficiency for corrosion of zinc in $\mathrm{HCl}$ solution and its inhibitive effect was discussed on the basis of the adsorption of its components on the zinc surface following Temkin isotherm.

Picralima nitida seed extract was investigated as a green inhibitor for corrosion of zinc in $0.5 \mathrm{M} \mathrm{H}_{2} \mathrm{SO}_{4}$ by J.N.O. Ezinga et al. (2018) [146] using weight loss method. The results indicated that this extract acted as an efficient inhibitor for corrosion of zinc in sulphuric acid solution. The protective action of the extract was discussed in view of Langmuir adsorption isotherm.

\section{II.5. Plant extracts as inhibitors for corrosion of nickel and its alloys}

Nickel and its alloys are used extensively in industry, air craft, marine, chemical, petrochemical, oil and gas, nuclear and conventional power generating, textile, desalination and food processing industries. Because their resistance to aqueous corrosion and to oxidative corrosion at elevated temperature. Nickel is an important constituent of super alloys, stainless steel and other alloys as well as providing protective coating for less corrosion resistance materials, these has been an ever increasing demand for nickel in the last four decades resulting in higher rates of production [147].

Nickel has good resistance to many corrosive solutions like slightly acidic and alkaline solutions so that it forms a good base for alloys requiring strength at high temperature. Nickel 
occupied an intermediate position in the electrochemical series $E_{0} \mathrm{Ni}^{2+} / \mathrm{Ni}=-0.25 \mathrm{~V}$, it is more noble than $\mathrm{Sn}, \mathrm{Pb}$ and $\mathrm{Cu}$ [148].

Many parts of new machines are made of pure nickel [149]. Nickel electrodes are important materials for petrochemical technology and energy conversion devices. In aqueous environments nickel electrodes are mainly covered by electrochemically active $\mathrm{Ni}(\mathrm{OH})_{2}$ layers, although in acid solution nickel corrosion and passivation takes place [150].

The aqueous extract of the leaves henna (Lawsonia) was tested as corrosion inhibitor for C-steel, nickel, and zinc in acid, neutral and alkaline solution by A.Y. El-Etre (2005) [151] using the polarization technique. It has been found that the extract acted as a good inhibitor for the corrosion of the three metals in all tested media. The extract acted as mixedtype inhibitor and its inhibitive effect was discussed on the basis of the adsorption of its ingredients molecules on the surface of the metal.

The inhibitive action of the extract of Ficus nitida leaves for general and pitting corrosion of C-steel, nickel and zinc in different aqueous media was studied by A.Y. El-Etre (2006) [152] using weight loss, potentiostatic and potentiodynamic polarization techniques. The results indicated that this extract inhibit the corrosion of the three metals in acidic, neutral and alkaline media. The inhibitive action of the extract was discussed on the basis of the adsorption of its ingredient molecules on the surface of the metal. The adsorption process obeyed the Langmuir adsorption isotherm.

Inhibition of the corrosion of nickel, Inconel 600 and Inconel 690 in $\mathrm{HCl}$ solution by natural Clove oil was studied by M. Abdallah et al. (2009) [153] using potentiodynamic polarization measurements. The inhibitive action of the oil was attributed to its adsorption onto the metal surface. The experimental results of inhibition obeys Langmuir isotherm.

The inhibitive effect of natural black cumin oil on the corrosion of nickel in $0.1 \mathrm{M} \mathrm{HCl}$ was studied by M. Abdallah et al. (2010) [154] using galvanostatic and potentiodynamic polarization techniques. The extract act as effective inhibitor for corrosion of nickel in the acid solution and its inhibition effect was discussed on the basis of the adsorption of its constituents on the surface of the metal. The adsorption process was controlled by Langmuir adsorption isotherm.

Cannabis plant extract as inhibitor for the corrosion of nickel in $0.5 \mathrm{M} \mathrm{H}_{2} \mathrm{SO}_{4}$ was studied by B.A. Abd-El-Naby et al. (2012) [155] using potentiodynamic polarization and electrochemical impedance spectroscopy techniques. The results indicated that this extract act as mixed-type inhibitor and serve as effective inhibitor for corrosion of nickel in sulphuric acid solution. Theoretical fitting of different adsorption isotherms, Langmuir, Flory-Huggins and the Kinetic-thermodynamic model were tested to clarify the nature of adsorption.

The inhibitive effect of some natural oil e.g. sesame oil, water cress oil, wheat germ oil and almond oil on the corrosion of nickel in $\mathrm{NaOH}$ solution was studied by $\mathrm{M}$. Abdallah (2014) [156] using open circuit measurements, galvanostatic and potentiostatic polarization techniques. The inhibitive effect of these oils was discussed on the basis of adsorption of 
these constituents on the surface of the metal. The adsorption process followed Freundlich isotherm.

\section{Plant extracts as scale inhibitors}

Scaling is the deposition of a mineral salt on processing equipment. It is a result of super saturation of mineral ions in the process fluid. The mineral salt can be either Calcium Carbonate or Barium Sulphate and so on [157].

Mineral scale deposits in industrial waters that support a number of processes represent a major problem leading to unexpected shutdowns and costly chemical or mechanical cleaning actions. There are many strategies to control scale formation including acidification, ion exchange softening, and scale inhibitors addition [158].

The environment concerns lead the research to develop new environmental friendly chemicals, currently named "Green" as scale inhibitors. The challenge is to determine the mechanisms of action of these chemicals against scale deposition to optimise their doses. There is already a need to develop a range of innovative antiscalants from materials of bioorigin because these have in-built multifunctional ion complexing and solubilizing functional groups such as carboxylic, hydroxyl, amine, or others [159]. Plant extracts have been recently used as new green antiscalants. Indeed, as they can be easily extracted and are environmentally friendly, they represent an interesting alternative source of "natural" organic molecules.

\section{III.1. Plant extracts for inhibition of Carbonate crystallization}

Miksic et al. (2005) [160] investigated the scale inhibition effect of soy bean extract and polysaccharides extracted from sea weeds using test methods described in a NACE Standard [161]. The authors reported that these extracts were more effective than polyaspartic acid in preventing calcium carbonate formation. Indeed, the percentage of inhibition was $16.7 \%$ for both soy based polymer and polysaccharides from sea weeds, whereas it was only $6.6 \%$ for polyaspartic acid.

Abdel-Gaber et al. (2008) [162] reported inhibition of $\mathrm{CaCO}_{3}$ scale performed with fig leaf extract. Stock solution of inhibitor was obtained from grinded dried leaves of fig tree by extraction in boiling distilled water. The $\mathrm{CaCO}_{3}$ deposition from an alkaline brine solution which models natural seawater was studied by chronoamperometry at $40^{\circ} \mathrm{C}$ on a steel electrode. Electrochemical Impedance Spectroscopy (EIS) measurements were also used to observe the nucleation, growth and total coverage at the surface electrode. Measurements were also used to observe the nucleation, growth and total coverage on the steel electrode surface. According to impedance data, the concentration of the solution necessary to obtain an inhibition efficiency of $85 \%$ was $75 \mathrm{mg} / \mathrm{L}$. In addition, optical microscopic examination indicated that, even at low concentration $(5 \mathrm{mg} / \mathrm{L})$, fig leaf extract could prevent total coverage of the steel electrode surface. The authors suggested that fig leaf extract may complex the cations present in the brine solution, or to disperse the suspended solids through adsorption. Also, the authors carried out the same study concerning the olive leaf extract 
(2001) [163]. Indeed, olive leaves contain many phenolic molecules including oleuropein, the most abundant biophenols in olive leaves [164] and caffeic acid [165, 166]. Stock solution of inhibitor was obtained from grinded dried leaves of olive tree by extraction in boiling distilled water. According to micrographic photos, the authors concluded that olive leaf extract acts as antiscalant by inhibiting nucleation step. These phenolic molecules may complex $\mathrm{Ca}^{2+}$ via their carboxyl and hydroxyl groups. A concentration of $50 \mathrm{mg} / \mathrm{L}$ of the olive leaf extract was found to be most effective for inhibition of calcium carbonate scaling. Even at low concentration $(5 \mathrm{mg} / \mathrm{L})$, addition of olive leaf extract is able to prevent total coverage stage of the steel electrode surface.

Moreover, Abdel-Gaber et al. (2012) [167] studied the antiscaling properties of Punica granatum hull and leaf extract in alkaline brine at $25^{\circ} \mathrm{C}$ using conductivity measurements, electrochemical impedance spectroscopy and chronoamperometry in conjunction with SEM, EDX and optical microscopic examinations. This work showed that the hull extract exhibited better antiscaling properties than leaf extract. Two major constituents of hull, i.e. the polyphenols punicalin and punicalagin, might be involved in the inhibition process. Microscopic examination of the filmformed over the steel electrode surface indicated that this process might take place via surface modification.

Castillo et al. (2009) [168] reported inhibition results of calcium carbonate scale performed with Aloe vera in Venezuelan oilfields. The scale inhibitor was obtained by dissolving Aloe vera gel in water at concentration in the range 5\%-50\% wt/wt. This solution contains polysaccharides [169] that can complex with $\mathrm{Ca}^{2+}$ ions. Some field tests were carried out on Venezuelan oil wells with water containing high bicarbonate ions (total calcium concentration of $535.4 \mathrm{mg} / \mathrm{L}$ ). Information on the inhibitory performance of Aloe vera are unfortunately limited. Weekly inspections of coupons performed during field tests with inhibitors ( 20 or 30 days of duration) led the authors to define the recommended concentration for the inhibitor. The Aloe vera solution was reported to provide very effective scale inhibition with a concentration of $15.2 \mathrm{mg} / \mathrm{L}$ (Barinas field test). Pressure and temperature were also recorded through the entire field test, and remained almost constant during the tests. This indicated the absence of precipitated solids in the system in the presence of Aloe vera.

Suharso et al. (2011) [170] reported Gambier extract from Uncaria gambier Roxb leaves as green inhibitor of $\mathrm{CaCO}_{3}$ scale formation. The addition of the Gambier extract (Uncaria gambier Roxb leaves) modification (Gambier:benzoic acid:citric acid / 2:1:2) as a green inhibitor on the formation of $\mathrm{CaCO}_{3}$ scale at various concentrations was carried out using a seeded experiment method. The experiments were performed with observing the precipitation change of the $\mathrm{CaCO}_{3}$ crystals growth obtained. In order to prove the efficiency of the inhibitor in inhibiting the formation of the $\mathrm{CaCO}_{3}$ crystals, the changes of the crystal morphology were investigated by scanning electron microscopy (SEM) and the changes of the crystal size distribution were analyzed by particle size analyzer (PSA).The research results showed that the Gambier extract modification was able to inhibit the formation of the $\mathrm{CaCO}_{3}$ scale indicated with the morphology change of the $\mathrm{CaCO}_{3}$ crystals and smaller crystal 
size distribution after the addition of this inhibitor. The modification of the Gambier extracts with the addition of benzoic and citric acid with the composition ratio of Gambier extract: benzoic acid:citric Acid / 2:1:2 in $1 \mathrm{~L}$ of water solution as green inhibitor increased the quality of this mixture. This mixture was able to inhibit the formation of $\mathrm{CaCO}_{3}$ scale at various inhibitor concentrations of 50-300 ppm and growth solution concentrations of $0.1-$ $0.6 \mathrm{M}$ using seeded experiment method with the inhibitor efficiency $(\% I E)$ of $12-92 \%$. The inhibitor used also changed the morphology of $\mathrm{CaCO}_{3}$ crystals and it made the crystal size of $\mathrm{CaCO}_{3}$ crystals to be smaller in their crystal size distribution after addition of this inhibitor.

Belarbi et al. (2014) [171, 172] carried out chronoamperometry experiments to test the scale inhibition performance of aqueous extract of Paranichia argentea. Stock solution of inhibitor $(20 \% \mathrm{w} / \mathrm{v})$ was obtained from grinded dried leaves and flowers of P. argentea by infusion in boiling distilled water. $P$. argentea acts as good antiscalant of $\mathrm{CaCO}_{3}$ formation on a copper surface. For inhibition of calcium carbonate scale, a concentration of $70 \mathrm{mg} / \mathrm{L}$ of the $P$. argentea extract was found to be the most effective concentration in carbonically pure water (concentration of $\mathrm{Ca}^{2+} 120 \mathrm{mg} / \mathrm{L}$ ). The authors indicated that the efficiency of this inhibitor was decreased at $60^{\circ} \mathrm{C}$, which could limit the interest for some industrial processes. Finally, SEM micrographs indicated, in the presence of low concentrations of $P$. argentea, highly deformed crystals of calcite and vaterite. This could be due to a partial covering of the crystal surface by the inhibitor. Different fractions were separated by HPLC from the stock solution; some of them were more efficient towards scale inhibition than the whole solution. Unfortunately, information about this purification process is limited [173]. Moreover, different commercially available biocides named B310, B320, B330 and B340 were also tested. The biocide B340 was the only found not compatible with green inhibitor.

Abd-El-Khalek, et al. (2016) [174] studied the antiscale properties of palm leaves extract (Phoenix dactylifera L) using electrochemical impedance spectroscopy (EIS) and chronoamperometry techniques, in addition to microscopic examination. Calcium carbonate scales were deposited from the brine solution by cathodic polarization of the steel surface at $-0.9 \mathrm{~V}$ (vs. SCE). Chronoamperometry curves and EIS measurements displayed that palm leaves extract increased the time of $\mathrm{CaCO}_{3}$ nuclei formation and consequently, retarded the growth step. The optical micrographs of the steel electrode clarified that the surface area occupied by the scale particles decreased with increasing plant extract concentrations. The results showed that palm leaves extract could be considered as efficient inhibitor for $\mathrm{CaCO}_{3}$ precipitation.

The anti-scale property of tobacco rob extract (TRE) in artificial seawater was studied by Wang et al. (2016) [175] using static tests for scale and the scale deposits such as X-ray diffraction (XRD) and SEM, respectively. The results showed that the scale deposits surface morphology and size were changed in the presence of TRE. The corrosion and scale inhibition results indicated the potential use of TRE as an efficient corrosion and scale inhibitor in artificial seawater. 
Bendaoud-Boulahlib et al. (2017) [176] studied the effect of orange peel on the $\mathrm{CaCO}_{3}$ precipitation in Algerian ground water of Bounouara having a hardness of $58^{\circ} \mathrm{F}$. The main objective was to reduce the scaling power and then to prevent the fouling phenomenon met in the equipments supplied by this water. Chronoamperometry tests showed that Bounouara water is extremely scale-forming water by scaling time of $(t E=9.17 \mathrm{~min})$ and an index scaling $\left(I E=107 \mathrm{~min}^{-1}\right)$. The accelerated scaling curves registered at different temperatures of raw water of Bounouara showed that scaling time decreases by increasing the temperature, and Bounouara water become more scale-forming in high temperatures. The anti-scale treatment with orange peel is more efficient in low temperature, because the total inhibition of hardness of Bounouara water was realized at $20^{\circ} \mathrm{C}$ with an addition of $0.75 \mathrm{~g} / \mathrm{L}$ of orange peel but at $40^{\circ} \mathrm{C}, 1 \mathrm{~g} / \mathrm{L}$ of orange peel must be added to Bounouara water to totally block the precipitation of tartar. So orange peel is an effective inhibitor for the scaling treatment of drinking water and for the valorization of orange peel and protection of the environment from food industry waste that reject $60 \%$ of citrus fruits in the form of waste.

The addition of the Gambier extract (Uncaria gambier Roxb leaves) modification (Gambier:benzoic acid: citric acid $=2: 1: 2$ ) as a green inhibitor on the formation of $\mathrm{CaCO}_{3}$ scale at various concentrations was carried out by Suharso et al. (2017) [177] using a seeded experiment method. The experiments were performed with observing the precipitation change of the $\mathrm{CaCO}_{3}$ crystals growth obtained. In order to prove the efficiency of the inhibitor in inhibiting the formation of the $\mathrm{CaCO}_{3}$ crystals, the changes of the crystal morphology were investigated by scanning electron microscopy (SEM) and the changes of the crystal size distribution were analyzed by particle size analyzer (PSA). The research results showed that the Gambier extract modification was able to inhibit the formation of the $\mathrm{CaCO}_{3}$ scale. indicated with the morphology change of the $\mathrm{CaCO}_{3}$ crystals and smaller crystal size distribution after the addition of this inhibitor.

Mohammadi et al. (2018) [178] examined Bistorta officinalis extract as an effective green inhibitor for prevention of scale formation problems in cooling water system. Electrochemical impedance spectroscopy, DC polarization, weight loss measurement and UV-Vis spectroscopy have been conducted to investigate the mechanism and performance of the proposed inhibitor. The Bistorta officinalis extract exhibited an excellent scale inhibition performance of $99.5 \%$ which make it an ideal material to prevent the scale formation in cooling water. Accordingly, the Bistorta officinalis extract could be proposed for effective treatment of cooling water systems.

The aqueous extract of Gypsophila aretioides roots as a "green" or eco-friendly inhibitor of calcium carbonate formation was investigated by Hajizadeh et al. (2019) [179]. The presence of chelating factors such as polyphenol compounds and foaming agents in the plant extract was assessed. Atomic absorption spectroscopy (AAS) demonstrated the ability of $G$. aretioides extract for dissolution of the calcium carbonate precipitates. Moreover, conductivity measurements revealed that the G. aretioides extract could efficiently retard sedimentation of calcium carbonate from a brine solution of calcium ions exposed to carbonate ions by adding $\mathrm{Na}_{2} \mathrm{CO}_{3}$ to the system solution. In addition, chronoamperometry 
was performed for a period of $3 \mathrm{~h}$ by polarizing the steel electrode to $-0.9 \mathrm{~V}$ ( $v s$. SCE) at $40^{\circ} \mathrm{C}$. The presence of G. aretioides extract at a concentration of $10 \%(\mathrm{w} / \mathrm{v})$ in chronoamperometry prevented the precipitation of $\mathrm{CaCO}_{3}$ on the steel electrode surface. This was confirmed by scanning electron microscopy (SEM) and energy dispersive X-ray (EDX) analyses which showed an absence of precipitates and lack of calcium ions on the steel electrode after $3 \mathrm{~h}$ chronoamperometry, respectively.

Vasyliev et al. (2020) [180] prepared Raphanus sativus L. ethanol extract by radish cake maceration in ethanol and tested this extract as a scale and corrosion inhibitor of mild steel in tap water. Antiscalant efficiency was tested with electrochemical and thermal scaling techniques, and changes in hardness content were determined titrimetrically. No deposits were found on the metal surface at the extract concentration of $10 \mathrm{~mL} / \mathrm{L}$ in chronoamperometry test, and scaling suppression was established 5 times in thermal scaling conditions. Corrosion Inhibition efficiency was found to be $75 \%$ in thermal scaling conditions. Formation of the surface film was responsible for both scaling and corrosion suppression on mild steel surface as was established with FT-IR spectroscopy and SEM. Surface film was found to contain polymerization products of isothiocyanates.

\section{III.2. Plant extract for inhibition of sulfate crystallization}

Abd-El-Khalek et al. (2019) [181] studied the antiscale properties of sunflower (Helianthus annuus) seed extract for $\mathrm{CaSO}_{4}$ and $\mathrm{BaSO}_{4}$ scales using NACE and conductivity tests, respectively. Comparative studies between the extract and 1-hydroxyethane-1,1diphosphonic acid (HEDP), as commercial antiscalant, were done. The results revealed that the inhibition of $\mathrm{CaSO}_{4}$ scales using sunflower seed extract reached $100 \%$, while HEDP achieved a maximum inhibition of $88 \%$. Moreover, the maximum inhibition of $\mathrm{BaSO}_{4}$ scale in the presence of the extract was $84 \%$ compared with $86 \%$ in the presence of HEDP. Also microscopic examination showed that both inhibitors modified $\mathrm{CaSO}_{4}$ and $\mathrm{BaSO}_{4}$ crystals.

The influence of Sargassum sp., Corallina mediterranea, and Avicennia marina on RO membrane mineral scaling was evaluated by Hamdona et al. (2019) [182] using gypsum as a model scalant. The degree of inhibition of gypsum scale in the presence of these inhibitors are in the following order: Avicennia marina $(\mathrm{M})>C$. Mediterranean $>$ Sargassum $s p$. extract at different dosage. data confirmed that the anti-scalant properties by $100 \mathrm{ppm}$ of Avicennia marina leave extract giving $85 \%$ of scale inhibition

Suharso et al. (2019) [183] studied the effect of the addition of gambier extract modified with kemenyan extract on the growth of calcium sulfate $\left(\mathrm{CaSO}_{4}\right)$ scale formation as a green inhibitor. The crystallization experiments were carried out by using unseeded experiment method at temperature of $90^{\circ} \mathrm{C}$. The $\mathrm{CaSO}_{4}$ crystals obtained with and without the addition of inhibitor were analyzed by scanning electron microscopy (SEM), particle size analyzer (PSA), and X-ray diffraction (XRD). The results of this experiment show that the addition of the combination of gambier and kemenyan extract with ratio of 5:9 can inhibit the growth of $\mathrm{CaSO}_{4}$ crystals with the inhibition effectivity of $39.88 \%$. These results were supported from the SEM and PSA data showing that the crystal size and particle size distribution of 
the $\mathrm{CaSO}_{4}$ in the addition of the inhibitor are smaller than without the addition of inhibitor. In addition, analysis using XRD showed that $\mathrm{CaSO}_{4}$ crystals undergo a change in crystalline phase with the addition of inhibitors.

The addition of Piper betle leaf extract with the concentration of $450 \mathrm{ppm}$ was tested by Santoso et al. (2019) [184] as a green inhibitor for $\mathrm{CaSO}_{4}$ scale formation at the concentration of growth solution of $0.05 \mathrm{M}$ and temperature of $90^{\circ} \mathrm{C}$ using a seeded experiment method. The experiments were performed with observing the precipitation change of $\mathrm{CaSO}_{4}$ crystals growth obtained. In order to prove the efficiency of the inhibitor in inhibiting the formation of $\mathrm{CaSO}_{4}$ crystals, the changes of the crystal morphology were investigated by scanning electron microscopy (SEM). The research results showed that Piper betle leaf extract was able to inhibit the formation of $\mathrm{CaSO}_{4}$ scale which was indicated with the morphology change of the $\mathrm{CaSO}_{4}$ crystals after the addition of this inhibitor. The ability of Piper betle leaf extract as an inhibitor of the formation of $\mathrm{CaSO}_{4}$ is $47.07 \%$.

\section{References}

1. M.M. Cowan, Plant Products as Antimicrobial Agents, Clin. Microbiol. Rev., 1999, 12, no. 4, 564-582. doi: 10.1128/CMR.12.4.564

2. R.P. Borris, Natural products research: perspectives from a major pharmaceutical company, J. Ethnopharmacol., 1996, 51, 29-38. doi: 10.1016/0378-8741(95)01347-4

3. U. Schippmann, D.J. Leaman and A.B. Cunningham, Impact of Cultivation and Gathering of Medicinal Plants on Biodiversity: Global Trends and Issues, 2002, Rome: FAO.

4. K. Springo and K. Saito, Metabolic engineering of plant secondary metabolism: Promising approach to the production of Pharmaceuticals, Sci. Cult., 2002, 68, 76-85.

5. J. Harborne, Methods of Plant Analysis. Phytochemical Methods, Dordrecht: Springer, 1984, 1-36.

6. https://www.marketsandmarkets.com/

7. S. Pirtarighat, M. Ghannadnia and S. Baghshahi, Green synthesis of silver nanoparticles using the plant extract of Salvia spinosa grown in vitro and their antibacterial activity assessment, J. Nanostruct. Chem., 2019, 9, 1-9. doi: 10.1007/s40097-018-0291-4

8. M.E. Cassiolato, M. Miyazawa, A.R. Meda and M.A. Pavan, A laboratory method to estimate the efficiency of plant extract to neutralize soil acidity, Braz. Arch. Biol. Technol., 2002, 45, no. 2, 183-187. doi: 10.1590/S1516-89132002000200009

9. O.K. Abiola, N.C. Oforka, E.E. Ebenso and N.M. Nwinuka, Eco-friendly corrosion inhibitors: the inhibitive action of Delonix Regia extract for the corrosion of aluminium in acidic media, Anti-Corros. Methods Mater., 2007, 54, no. 4, 219-224. doi: $\underline{10.1108 / 00035590710762357}$

10. D.E. Arthur, A. Jonathan, P.O. Ameh and C. Anya, A review on the assessment of polymeric materials used as corrosion inhibitor of metals and alloys, Int. J. Ind. Chem., 2013, 4, no. 1, 2. doi: $10.1186 / 2228-5547-4-2$ 
11. L. Nnanna, G. Nnanna, N.D. Ekekwe, J. Nnakaife and P. Eti, Aqueous extracts of pentaclethra macrophylla bentham roots as eco-friendly corrosion inhibition for mild steel in $0.5 \mathrm{M} \mathrm{KOH}$ medium, Int. J. Mater. Chem., 2016, 6, no. 1, 12-18. doi: 10.5923/j.ijmc.20160601.03

12. B.E. Rani and B.B.J. Basu, Green inhibitors for corrosion protection of metals and alloys: an overview, Int. J. Corros., 2012, 380217. doi: 10.1155/2012/380217

13. J. Halambek, K. Berković and J. Vorkapić-Furač, Laurus nobilis L. oil as green corrosion inhibitor for aluminium and AA5754 aluminium alloy in $3 \% \mathrm{NaCl}$ solution, Mater. Chem. Phys., 2013, 137, no. 3, 788-795. doi: j.matchemphys.2012.09.066

14. D. Kesavan, M. Gopiraman and N. Sulochana, Green inhibitors for corrosion of metals: a review, Chem. Sci. Rev. Lett., 2012, 1, no. 1, 1-8.

15. M.S. Khorrami, M.A. Mostafaei, H. Pouraliakbar and A.H. Kokabi, Study on microstructure and mechanical characteristics of low-carbon steel and ferritic stainless steel joints, Mater. Sci. Eng.: A, 2014, 608, 35-45. doi: 10.1016/j.msea.2014.04.065

16. T.J. Tuaweri, E.A. Ogbonnaya and O.O. Onyemaobi, Corrosion inhibition of heat treated mild steel with neem leave extract in a chloride medium, Int. J. Res. Eng. Technol., 2015, 4, no. 6, 404-409. doi: 10.15623/ijret.2015.0406069

17. G. Gunasekaran and L.R. Chauhan, Eco friendly inhibitor for corrosion inhibition of mild steel in phosphoric acid medium, Electrochim. Acta, 2004, 49, no. 25, 4387-4395. doi: $10.1016 /$ j.electacta.2004.04.030

18. K.O. Orubite and N.C. Oforka, Inhibition of the corrosion of mild steel in hydrochloric acid solutions by the extracts of leaves of Nypa fruticans Wurmb, Mater. Lett., 2004, 58, no. 11, 1768-1772. doi: 10.1016/j.matlet.2003.11.030

19. A.M. Abdel-Gaber, B.A. Abd-El-Nabey, I.M. Sidahmed, A.M. El-Zayady and M. Saadawy, Inhibitive action of some plant extracts on the corrosion of steel in acidic media, Corros. Sci., 2006, 48, no. 9, 2765-2779. doi: 10.1016/j.corsci.2005.09.017

20. S.S.D.A.A. Pereira, M.M. Pegas, T.L. Fernandez, M. Magalhaes, T.G. Schöntag, D.C. Lago, L.F. de Senna and E. D'Elia, Inhibitory action of aqueous garlic peel extract on the corrosion of carbon steel in $\mathrm{HCl}$ solution, Corros. Sci., 2012, 65, 360-366. doi: 10.1016/j.corsci.2012.08.038

21. K. Krishnaveni, J. Ravichandran and A. Selvaraj, Effect of Morinda tinctoria leaves extract on the corrosion inhibition of mild steel in acid medium, Acta Metall. Sin. (Engl. Lett.), 2013, 26, no. 3, 321-327. doi: 10.1007/s40195-012-0219-9

22. A.E. Okoronkwo, S.J. Olusegun and O.O. Oluwasina, The inhibitive action of chitosan extracted from Archachatina marginata shells on the corrosion of plain carbon steel in acid media, Anti-Corros. Methods Mater., 2015. doi: 10.1108/ACMM-10-2013-1307

23. G. Ji, S. Anjum, S. Sundaram and R. Prakash, Musa paradisica peel extract as green corrosion inhibitor for mild steel in HCl solution, Corros. Sci., 2015, 90, 107-117. doi: $\underline{10.1016 / j . c o r s c i .2014 .10 .002 ~}$ 
24. H. Ashassi-Sorkhabi, S. Mirzaee, T. Rostamikia and R. Bagheri, Pomegranate (Punica granatum) peel extract as a green corrosion inhibitor for mild steel in hydrochloric acid solution, Int. J. Corros., 2015, 197587. doi: 10.1155/2015/197587

25. E. Baran, A. Cakir and B. Yazici, Inhibitory effect of Gentiana olivieri extracts on the corrosion of mild steel in $0.5 \mathrm{M} \mathrm{HCl}$ : Electrochemical and phytochemical evaluation, Arabian J. Chem., 2019, 12, no. 8, 4303-4319. doi: 10.1016/j.arabjc.2016.06.008

26. K.K. Anupama, K. Ramya and A. Joseph, Electrochemical and computational aspects of surface interaction and corrosion inhibition of mild steel in hydrochloric acid by Phyllanthus amarus leaf extract (PAE), J. Mol. Liq., 2016, 216, 146-155. doi: 10.1016/j.molliq.2016.01.019

27. G. Singh, S.K. Arora, A. Tripathy and M. Dochania, Inhibitive action of Leptadenia pyrotechnica extract on the corrosion of Mild Steel in $\mathrm{H}_{2} \mathrm{SO}_{4}$ solution, J. Integr. Sci. Technol., 2016, 4, no. 2, 76-80.

28. B.A. Abd-El-Nabey, S. El-Housseiny, G.A. El-Naggar, E.A. Matter and G. Esmail, Green Inhibitors for the Acidic Corrosion of Steel, Phys. Chem., 2016, 6, 57-66. doi: 10.5923/j.pc.20160603.01

29. N. Asadi, M. Ramezanzadeh, G. Bahlakeh and B. Ramezanzadeh, Utilizing Lemon Balm extract as an effective green corrosion inhibitor for mild steel in $1 \mathrm{M} \mathrm{HCl} \mathrm{solution:}$ A detailed experimental, molecular dynamics, Monte Carlo and quantum mechanics study, J. Taiwan Inst. Chem. Eng., 2019, 95, 252-272. doi: 10.1016/j.jtice.2018.07.011

30. M. Pramudita, S. Sukirno and M. Nasikin, Synergistic Corrosion Inhibition Effect of Rice Husk Extract and KI for Mild Steel in $\mathrm{H}_{2} \mathrm{SO}_{4}$ Solution, Bull. Chem. React. Eng. Catal., 2019, 14, no. 3, 697-704. doi: 10.9767/bcrec.14.3.4249.697-704

31. G. Bahlakeh, B. Ramezanzadeh, A. Dehghani and M. Ramezanzadeh, Novel costeffective and high-performance green inhibitor based on aqueous Peganum harmala seed extract for mild steel corrosion in $\mathrm{HCl}$ solution: Detailed experimental and electronic/atomic level computational explorations, J. Mol. Liq., 2019, 283, 174-195. doi: $10.1016 /$ j.molliq.2019.03.086

32. G. Bahlakeh, A. Dehghani, B. Ramezanzadeh and M. Ramezanzadeh, Highly effective mild steel corrosion inhibition in $1 \mathrm{M} \mathrm{HCl}$ solution by novel green aqueous Mustard seed extract: Experimental, electronic-scale DFT and atomic-scale MC/MD explorations, $J$. Mol. Liq., 2019, 293, 111559. doi: 10.1016/j.molliq.2019.111559

33. M. Benarioua, A. Mihi, N. Bouzeghaia and M. Naoun, Mild steel corrosion inhibition by Parsley (Petroselium Sativum) extract in acidic media, Egypt. J. Pet., 2019, 28, no. 2, 155-159. doi: 10.1016/j.ejpe.2019.01.001

34. A. Dehghani, G. Bahlakeh, B. Ramezanzadeh and M. Ramezanzadeh, Potential of Borage flower aqueous extract as an environmentally sustainable corrosion inhibitor for acid corrosion of mild steel: electrochemical and theoretical studies, J. Mol. Liq., 2019, 277, 895-911. doi: 10.1016/j.molliq.2019.01.008 
35. A. Dehghani, G. Bahlakeh, B. Ramezanzadeh and M. Ramezanzadeh, Electronic/atomic level fundamental theoretical evaluations combined with electrochemical/surface examinations of Tamarindus indiaca aqueous extract as a new green inhibitor for mild steel in acidic solution (HCl 1 M), J. Taiwan Inst. Chem. Eng., 2019, 102, 349-377. doi: 10.1016/j.jtice.2019.05.006

36. V.C. Anadebe, O.D. Onukwuli, M. Omotioma and N.A. Okafor, Experimental, theoretical modeling and optimization of inhibition efficiency of pigeon pea leaf extract as anti-corrosion agent of mild steel in acid environment, Mater. Chem. Phys., 2019, 233, 120-132. doi: 10.1016/j.matchemphys.2019.05.033

37. A. Dehghani, G. Bahlakeh, B. Ramezanzadeh and M. Ramezanzadeh, Potential role of a novel green eco-friendly inhibitor in corrosion inhibition of mild steel in $\mathrm{HCl}$ solution: Detailed macro/micro-scale experimental and computational explorations, Constr. Build. Mater., 2020, 245, 118464. doi: 10.1016/j.conbuildmat.2020.118464

38. A. Sedik, D. Lerari, A. Salci, S. Athmani, K. Bachari, İ.H. Gecibesler and R. Solmaz, Dardagan Fruit extract as eco-friendly corrosion inhibitor for mild steel in $1 \mathrm{M} \mathrm{HCl}$ : Electrochemical and surface morphological studies, J. Taiwan Inst. Chem. Eng., 2020, 107, 189-200. doi: 10.1016/j.jtice.2019.12.006

39. A. Saxena, K.K. Thakur, K.K. Saxena, S. Chambyal and A. Sharma, Electrochemical studies and surface examination of low carbon steel by applying the extract of Terminalia chebula, Mater. Today: Proc., 2020, 26, 1360-1367. doi: 10.1016/j.matpr.2020.02.276

40. A. Saxena, K.K. Thakur and N. Bhardwaj, Electrochemical studies and surface examination of low carbon steel by applying the extract of Musa acuminata, Surf. Interfaces, 2020, 18, 100436. doi: 10.1016/j.surfin.2020.100436

41. A.M. Abdel-Gaber, B.A. Abd-El-Nabey, E. Khamis and D.E. Abd-El-Khalek, A natural extract as scale and corrosion inhibitor for steel surface in brine solution, Desalination, 2011, 278, no. 1-3, 337-342. doi: 10.1016/j.desal.2011.05.048

42. E. Akbarzadeh, M.M. Ibrahim and A.A. Rahim, Corrosion inhibition of mild steel in near neutral solution by kraft and soda lignins extracted from oil palm empty fruit bunch, Int. J. Electrochem. Sci., 2011, 6, no. 11, 5396-5416.

43. M. Sangeetha, S. Rajendran, J. Sathiyabama, A. Krishnaveni, P. Shanthy, N. Manimaran and B. Shyamaladevi, Corrosion inhibition by an aqueous extract of Phyllanthus amarus, Port. Electrochim. Acta, 2011, 29, no. 6, 429-444. doi: 10.4152/pea.201106429

44. D.E. Abd-El-Khalek and A.M. Abdel-Gaber, Evaluation of Nicotiana leaves extract as corrosion inhibitor for steel in acidic and neutral chloride solutions, Port. Electrochim. Acta, 2012, 30, no. 4, 247-259. doi: 10.4152/pea.201204247

45. D. Asra Awizar, N.K. Othman, A.R. Daud, A. Jalar and R. Zulkafli, The performance of nanosilicate from rice husk ash as green corrosion inhibitor for carbon steel in $0.5 \mathrm{M}$ HCl, Mater. Sci. Forum, Trans Tech Publications Ltd., 2013, 756, 266-272. doi: 10.4028/www.scientific.net/MSF.756.266 
46. V. Johnsirani, J. Sathiyabama, S. Rajendran, S.M. Christyc and J. Jeyasundari, The Effect of Eclipta Alba Leaves Extract on the Corrosion Inhibition Process of Carbon Steel in Sea Water, Port. Electrochim. Acta, 2013, 31, no. 2, 95-106. doi: 10.4152/pea.201302095

47. H. Wang, M. Gao, Y. Guo, Y. Yang and R. Hu, A natural extract of tobacco rob as scale and corrosion inhibitor in artificial seawater, Desalination, 2016, 398, 198-207. doi: 10.1016/j.desal.2016.07.035

48. M. A. Deyab, Inhibition activity of Seaweed extract for mild carbon steel corrosion in saline formation water, Desalination, 2016, 384, 60-67. doi: 10.1016/j.desal.2016.02.001

49. P. Parthipan, J. Narenkumar, P. Elumalai, P.S. Preethi, A.U.R. Nanthini, A. Agrawal and A. Rajasekar, Neem extract as a green inhibitor for microbiologically influenced corrosion of carbon steel API 5LX in a hypersaline environments, J. Mol. Liq., 2017, 240, 121-127. doi: $10.1016 /$ j.molliq.2017.05.059

50. M.A. Deyab, M.M. Osman, A.E. Elkholy and F.E.T. Heakal, Green approach towards corrosion inhibition of carbon steel in produced oilfield water using lemongrass extract, RSC Adv., 2017, 7, no. 72, 45241-45251. doi: 10.1039/C7RA07979F

51. K. Nasr, M. Fedel, K. Essalah, F. Deflorian and N. Souissi, Experimental and theoretical study of Matricaria recutita chamomile extract as corrosion inhibitor for steel in neutral chloride media, Anti-Corros. Methods Mater., 2018, 65, no. 3, 292-309. doi: 10.1108/ACMM-12-2017-1869

52. V. Grudić, I. Bošković, S. Martinez and B. Knežević, Corrosion inhibition mild steel in $\mathrm{NaCl}$ solution in the presence of propolis extract, Maced. J. Chem. Chem. Eng., 2018, 37, no. 2, 203. doi: $10.20450 /$ mjcce. 2018.1513

53. F.E.T. Heakal, M.A. Deyab, M.M. Osman and A.E. Elkholy, Performance of Centaurea cyanus aqueous extract towards corrosion mitigation of carbon steel in saline formation water, Desalination, 2018, 425, 111-122. doi: 10.1016/j.desal.2017.10.019

54. Z. Mohammadi and M. Rahsepar, Characterization of Mazuj galls of Quercus infectoria tree as green corrosion and scale inhibitor for effective treatment of cooling water systems, Res. Chem. Intermed., 2018, 44, no. 3, 2139-2155. doi: 10.1007/s11164-017$\underline{3219-6}$

55. S. Devikala, P. Kamaraj, M. Arthanareeswari and S. Pavithra, Green Corrosion inhibition of mild steel by Asafoetida extract extract in 3.5\% NaCl, Mater. Today: Proc., 2019, 14, 590-601. doi: 10.1016/j.matpr.2019.04.183

56. S.A. Haddadi, E. Alibakhshi, G. Bahlakeh, B. Ramezanzadeh and M. Mahdavian, A detailed atomic level computational and electrochemical exploration of the Juglans regia green fruit shell extract as a sustainable and highly efficient green corrosion inhibitor for mild steel in $3.5 \mathrm{wt} \% \mathrm{NaCl}$ solution, J. Mol. Liq., 2019, 284, 682-699. doi: $\underline{10.1016 / j . m o l l i q .2019 .04 .045}$ 
57. Z. Sanaei, G. Bahlakeh, B. Ramezanzadeh and M. Ramezanzadeh, Application of green molecules from Chicory aqueous extract for steel corrosion mitigation against chloride ions attack; the experimental examinations and electronic/atomic level computational studies, J. Mol. Liq., 2019, 290, 111176. doi: 10.1016/j.molliq.2019.111176

58. M.T. majd, G. Bahlakeh, A. Dehghani, B. Ramezanzadeh and M. Ramezanzadeh, Combined molecular simulation, DFT computation and electrochemical studies of the mild steel corrosion protection against $\mathrm{NaCl}$ solution using aqueous Eucalyptus leaves extract molecules linked with zinc ions, J. Mol. Liq., 2019, 294, 111550. doi: 10.1016/j.molliq.2019.111550

59. M.T. majd, G. Bahlakeh, A. Dehghani, B. Ramezanzadeh and M. Ramezanzadeh, A green complex film based on the extract of Persian Echium amoenum and zinc nitrate for mild steel protection in saline solution; Electrochemical and surface explorations besides dynamic simulation, J. Mol. Liq., 2019, 291, 111281. doi: 10.1016/j.molliq.2019.111281

60. M.T. Majd, M. Ramezanzadeh, B. Ramezanzadeh and G. Bahlakeh, Production of an environmentally stable anti-corrosion film based on Esfand seed extract molecules-metal cations: Integrated experimental and computer modeling approaches, J. Hazard. Mater., 2020, 382, 121029. doi: 10.1016/j.jhazmat.2019.121029

61. H.A. Fetouh, B.A. Abd-El-Nabey, Y.M. Goher and M.S. Karam, Electrochemical Investigation of the Anticorrosive Properties of Silver Nanoparticles for the Acidic Corrosion of Aluminium, J. Electrochem., 2017, 23, 89-100.

62. T. Alam and A.H. Ansari, Review on Aluminium and Its Alloys for automotive applications, Int. J. Adv. Technol. Eng. Sci., 2017, 5, no. 5, 278-294.

63. B.A. Abd-El-Nabey, A.M. Abdel-Gaber, G.Y. Elawady and S. El-Houssein, Inhibitive action of some plant extracts on the alkaline corrosion of aluminum, Int. J. Electrochem. Sci., 2012, 7, 7823-7839.

64. A.A. El Hosary, R.M. Saleh and A.S. El Din, Corrosion inhibition by naturally occurring substances - I. The effect of Hibiscus subdariffa (karkade) extract on the dissolution of Al and Zn, Corros. Sci., 1972, 12, no. 12, 897-904. doi: 10.1016/S0010938X(72)80098-2

65. A.A. El Hosary and R.M. Saleh, Progress in Understanding and Prevention of Corrosion, 2, The Institute of Materials, London, 1993, 911.

66. G.O. Avwiri and F.O. Igho, Inhibitive action of Vernonia amygdalina on the corrosion of aluminium alloys in acidic media, Mater. Lett., 2003, 57, no. 22-23, 3705-3711. doi: 10.1016/S0167-577X(03)00167-8

67. A.Y. El-Etre, Inhibition of aluminum corrosion using Opuntia extract, Corros. Sci., 2003, 45, no. 11, 2485-2495. doi: 10.1016/S0010-938X(03)00066-0

68. I.B. Obot and N.O. Obi-Egbedi, An interesting and efficient green corrosion inhibitor for aluminium from extracts of Chlomolaena odorata L. in acidic solution, J. Appl. Electrochem., 2010, 40, no. 11, 1977-1984. doi: 10.1007/s10800-010-0175-x 
69. O.K. Abiola and Y. Tobun, Cocos nucifera L. water as green corrosion inhibitor for acid corrosion of aluminium in $\mathrm{HCl}$ solution, Chin. Chem. Lett., 2010, 21, no. 12, 1449-1452. doi: $10.1016 /$ j.cclet.2010.07.008

70. I.B. Obot, S.A. Umoren and N.O. Obi-Egbedi, Corrosion inhibition and adsorption behaviour for aluminuim by extract of Aningeria robusta in $\mathrm{HCl}$ solution: Synergistic effect of iodide ions, J. Mater. Environ. Sci., 2011, 2, no. 1, 60-71.

71. L.A. Nnanna, I.U. Anozie, A.G.I. Avoaja, C.S. Akoma and E.P. Eti, Comparative study of corrosion inhibition of aluminium alloy of type AA3003 in acidic and alkaline media by Euphorbia hirta extract, Afr. J. Pure Appl. Chem., 2011, 5, no. 8, 265-271.

72. M.M. Fares, A.K. Maayta and M.M. Al-Qudah, Pectin as promising green corrosion inhibitor of aluminum in hydrochloric acid solution, Corros. Sci., 2012, 60, 112-117. doi: $10.1016 / j$.corsci.2012.04.002

73. X. Li and S. Deng, Inhibition effect of Dendrocalamus brandisii leaves extract on aluminum in $\mathrm{HCl}, \mathrm{H} 3 \mathrm{PO} 4$ solutions, Corros. Sci., 2012, 65, 299-308. doi: 10.1016/j.corsci.2012.08.033

74. S. Deng and X. Li, Inhibition by Jasminum nudiflorum Lindl. leaves extract of the corrosion of aluminium in $\mathrm{HCl}$ solution, Corros. Sci., 2012, 64, 253-262. doi: 10.1016/j.corsci.2012.07.017

75. A.I. Ali and N. Foaud, Inhibition of aluminum corrosion in hydrochloric acid solution using black mulberry extract, J. Mater. Environ. Sci., 2012, 3, no 5, 917-924.

76. P.O. Ameh and N.O. Eddy, Commiphora pedunculata gum as a green inhibitor for the corrosion of aluminium alloy in $0.1 \mathrm{M} \mathrm{HCl}$, Res. Chem. Intermed., 2014, 40, no. 8, 2641-2649. doi: $10.1007 / \mathrm{s} 11164-013-1117-0$

77. A. Nithya, P. Shanthy, N. Vijaya, R.J. Rathish, S.S. Prabha, R.M. Joany and S. Rajendran, Inhibition of Corrosion of Aluminium by an aqueous extract of beetroot (Betanin), Int. J. Nano. Corr. Sci. Engg., 2015, 2, no. 1, 1-11.

78. M. Akin, S. Nalbantoglu, O. Cuhadar, D. Uzun and N. Saki, Juglans regia L. extract as green inhibitor for stainless steel and aluminium in acidic media, Res. Chem. Intermed., 2015, 41, no. 2, 899-912. doi: 10.1007/s11164-013-1241-x

79. A. Khadraoui, A. Khelifa, K. Hachama and R. Mehdaoui, Thymus algeriensis extract as a new eco-friendly corrosion inhibitor for 2024 aluminium alloy in $1 \mathrm{M} \mathrm{HCl}$ medium, $J$. Mol. Liq., 2016, 214, 293-297. doi: 10.1016/j.molliq.2015.12.064

80. Y.C. Sharma and S. Sharma, Corrosion Inhibition of Aluminum by Psidium Guajava Seeds in $\mathrm{HCl}$ Solution, Port. Electrochim. Acta, 2016, 34, no. 6, 365-382. doi: 10.4152/pea.201606365

81. O.U. Abakedi and I.E. Moses, Aluminium corrosion inhibition by Maesobatrya barteri root extract in hydrochloric acid solution, Chem. Sci. Int. J., 2016, 1-10. doi: 10.9734/ACSJ/2016/21812 
82. Y.T. Du, H.L. Wang, Y.R. Chen, H.P. Qi and W.F. Jiang, Synthesis of baicalin derivatives as eco-friendly green corrosion inhibitors for aluminum in hydrochloric acid solution, J. Environ. Chem. Eng., 2017, 5, no. 6, 5891-5901. doi: 10.1016/j.jece.2017.11.004

83. M. Prabakaran, S.H. Kim, A. Sasireka, K. Kalaiselvi and I.M. Chung, Polygonatum odaratum extract as an eco-friendly inhibitor for aluminum corrosion in acidic medium, J. Adhes. Sci. Technol., 2018, 32, no. 18, 2054-2069. doi: $\underline{10.1080 / 01694243.2018 .1462947}$

84. N. Raghavendra and J.I. Bhat, Anti-corrosion properties of areca palm leaf extract on aluminium in $0.5 \mathrm{M} \mathrm{HCl}$ environment, S. Afr. J. Chem., 2018, 71, 30-38. doi: 10.17159/0379-4350/2018/v71a4

85. S. Bashir, G. Singh and A. Kumar, Shatavari (Asparagus Racemosus) as green corrosion inhibitor of aluminium in acidic medium, Port. Electrochim. Acta, 2019, 37, no. 2, 8391. doi: $10.4152 /$ pea.201902083

86. E.E. Oguzie, Corrosion inhibition of aluminium in acidic and alkaline media by Sansevieria trifasciata extract, Corros. Sci., 2007, 49, no. 3, 1527-1539. doi: 10.1016/j.corsci.2006.08.009

87. A.M. Abdel-Gaber, E. Khamis, H. Abo-ElDahab and S. Adeel, Inhibition of aluminium corrosion in alkaline solutions using natural compound, Mater. Chem. Phys., 2008, 109, no. 2-3, 297-305. doi: 10.1016/j.matchemphys.2007.11.038

88. O.K. Abiola, J.O.E. Otaigbe and O.J. Kio, Gossipium hirsutum L. extracts as green corrosion inhibitor for aluminum in $\mathrm{NaOH}$ solution, Corros. Sci., 2009, 51, no. 8, 18791881. doi: $10.1016 /$ j.corsci.2009.04.016

89. R. Rosliza and W.W. Nik, Improvement of corrosion resistance of AA6061 alloy by tapioca starch in seawater, Curr. Appl. Phys., 2010, 10, no. 1, 221-229. doi: 10.1016/j.cap.2009.05.027

90. J. Halambek, K. Berković and J. Vorkapić-Furač, The influence of Lavandula angustifolia L. oil on corrosion of Al-3Mg alloy, Corros. Sci., 2010, 52, no. 12, $3978-$ 3983. doi: 10.1016/j.corsci.2010.08.012

91. S. Ambrish and M.A. Quraishi, Azwain (Trachyspermum copticum) seed extract as an efficient corrosion Inhibitor for Aluminium in $\mathrm{NaOH}$ solution, Res. J. Recent Sci., 2012, 1, 57-61.

92. D. Prabhu and P. Rao, Inhibiting Action of fruits of Terminalia chebula on 6063 aluminum alloy in sodium hydroxide solution, J. Mater. Environ. Sci., 2015, 6, no. 2, 412-424.

93. E.M. Nawafleh, T.T. Bataineh, M.K. Irshedat, M.A. Al-Qudah and S.T.A. Orabi, Inhibition of Aluminum Corrosion by Salvia Judica Extract, Res. J. Chem. Sci., 2013, 3, $68-72$.

94. S. Geetha, S. Lakshmi and K. Bharathi, Corrosion inhibition of aluminium in alkaline medium using Vitex negundo leaves extract, Int. J. Adv. Sci. Tech. Res., 2013, 3, 258268. 
95. J. Halambek, K. Berković and J. Vorkapić-Furač, Laurus nobilis L. oil as green corrosion inhibitor for aluminium and AA5754 aluminium alloy in $3 \% \mathrm{NaCl}$ solution, Mater. Chem. Phys., 2013, 137, no. 3, 788-795. doi: 10.1016/j.matchemphys.2012.09.066

96. M.K. Irshedat, E.M. Nawafleh, T.T. Bataineh, R. Muhaidat, M.A. Al-Qudah and A.A. Alomary, Investigations of the inhibition of aluminum corrosion in $1 \mathrm{M} \mathrm{NaOH}$ solution by Lupinus varius l. Extract, Port. Electrochim. Acta, 2013, 31, no. 1, 1-10. doi: $10.4152 /$ pea.201301001

97. T.T. Bataineh, M.A. Al-Qudah, E.M. Nawafleh and N.A. Al-Rawashdeh, Sinapis alba extract as green corrosion inhibitor for aluminum in alkaline media, Int. J. Electrochem. Sci., 2014, 9, 3543-3557.

98. H.A. Fetouh, T.M. Abdel-Fattah and M.S. El-Tantawy, Novel plant extracts as green corrosion inhibitors for 7075-T6 aluminium alloy in an aqueous medium, Int. J. Electrochem. Sci., 2014, 9, 1565-1582.

99. H. Gerengi, A. Jazdzewska and M. Kurtay, A comprehensive evaluation of mimosa extract as a corrosion inhibitor on AA6060 alloy in acid rain solution: part I. Electrochemical AC methods, J. Adhes. Sci. Technol., 2015, 29, no 1, 36-48. doi: $\underline{10.1080 / 01694243.2014 .973159}$

100. N. Chaubey, V.K. Singh and M.A. Quraishi, Alstonia Scholaris bark as an environmentally benign corrosion inhibitor for aluminium alloy in sodium hydroxide solution, J. Mater. Environ. Sci., 2016, 7, 2453-2467.

101. N. Chaubey, V.K. Singh, Savita, M.A. Quraishi and E.E. Ebenso, Corrosion inhibition of aluminium alloy in alkaline media by Neolamarkia cadamba bark extract as a green inhibitor, Int. J. Electrochem. Sci., 2015, 10, 504-518.

102. N. Chaubey, V.K. Singh and M.A. Quraishi, Effect of some peel extracts on the corrosion behavior of aluminum alloy in alkaline medium, Int. J. Ind. Chem., 2015, 6, no. 4, 317-328. doi: 10.1007/s40090-015-0054-8

103. M.M.A. Qudah, Inhibition of Aluminum in $\mathrm{NaOH}$ Solution using Cleome droserifolia Leaves Extract, Res. Rev.: J. Chem., 2015, 14, 40-45.

104. N. Chaubey, D.K. Yadav, V.K. Singh and M.A. Quraishi, A comparative study of leaves extracts for corrosion inhibition effect on aluminium alloy in alkaline medium, Ain Shams Eng. J., 2017, 8, no. 4, 673-682. doi: 10.1016/j.asej.2015.08.020

105. N. Chaubey, V.K. Singh and M.A. Quraishi, Electrochemical approach of Kalmegh leaf extract on the corrosion behavior of aluminium alloy in alkaline solution, Int. J. Ind. Chem., 2017, 8, no. 1, 75-82. doi: 10.1007/s40090-016-0103-y

106. N. Chaubey, Savita, V.K. Singh and M.A. Quraishi, Corrosion inhibition performance of different bark extracts on aluminium in alkaline solution, J. Assoc. Arab Univ. Basic Appl. Sci., 2017, 22, no. 1, 38-44. doi: 10.1016/j.jaubas.2015.12.003

107. H. Elgahawi, M. Gobara, A. Baraka and W. Elthalabawy, Eco-friendly corrosion inhibition of AA2024 in 3.5\% NaCl using the extract of Linum usitatissimum seeds, $J$. Bio- Tribo-Corros., 2017, 3, no. 4, 55, 2-13. doi: 10.1007/s40735-017-0116-X 
108. N. Raghavendra and J.I. Bhat, Benevolent Behavior of Arecanut Husk Extracts as Potential Corrosion Inhibitor for Aluminum in both $0.5 \mathrm{M} \mathrm{HCl}$ and $0.1 \mathrm{M} \mathrm{NaOH}$ Environments, J. Bio- Tribo-Corros., 2018, 4, no. 3, 44, 2-12. doi: 10.1007/s40735-018$\underline{0159-7}$

109. K. Zhang, W. Yang, B. Xu, Y. Chen, X. Yin, Y. Liu and H. Zuo, Inhibitory effect of konjac glucomanan on pitting corrosion of AA5052 aluminium alloy in $\mathrm{NaCl}$ solution, J. Colloid Interface Sci., 2018, 517, 52-60. doi: 10.1016/j.jcis.2018.01.092

110. J. Ryl, J. Wysocka, M. Cieslik, H. Gerengi, T. Ossowski, S. Krakowiak and P. Niedzialkowski, Understanding the origin of high corrosion inhibition efficiency of bee products towards aluminium alloys in alkaline environments, Electrochim. Acta, 2019, 304, 263-274. doi: 10.1016/j.electacta.2019.03.012

111. P. Rathi and S. Kumar, Anticorrosive Effect of Tribulus terrestris on Aluminium in Basic Media, Surf. Eng. Appl. Electrochem., 2019, 55, no. 4, 430-435. doi: 10.3103/S1068375519040124

112. K.F. Khaled, Guanidine derivative as a new corrosion inhibitor for copper in $3 \% \mathrm{NaCl}$ solution, Mater. Chem. Phys., 2008, 112, no. 1, 104-111. doi: 10.1016/j.matchemphys.2008.05.052

113. E.M. Sherif and S.M. Park, 2-Amino-5-ethyl-1,3,4-thiadiazole as a corrosion inhibitor for copper in $3.0 \% \mathrm{NaCl}$ solutions, Corros. Sci., 2006, 48, no. 12, 4065-4079. doi: 10.1016/j.corsci.2006.03.011

114. Y. Chen, S. Chen, F. Yu, W. Sun, H. Zhu and Y. Yin, Fabrication and anti-corrosion property of superhydrophobic hybrid film on copper surface and its formation mechanism, Surf. Interface Anal., 2009, 41, no. 11, 872-877. doi: 10.1002/sia.3102

115. N.A. Al-Mobarak, K.F. Khaled, O.A. Elhabib and K.M. Abdel-Azim, Electrochemical investigation of corrosion and corrosion inhibition of copper in $\mathrm{NaCl}$ solutions, J. Mater. Environ. Sci., 2010, 1, no. 9.

116. T.V. Sangeetha and M. Fredimoses, Inhibition of mild copper metal corrosion in $\mathrm{HNO}_{3}$ medium by acid extract of Azadirachta indica seed, J. Chem., 2011, 8, no. S1, 135952. doi: $10.1155 / 2011 / 135952$

117. A.M. Shah, A.A. Rahim, S.A. Hamid and S. Yahya, Green inhibitors for copper corrosion by mangrove tannin, Int. J. Electrochem. Sci., 2013, 8, no. 2, 2140-2153.

118. B.A. Abd-El-Nabey, A.M. Abdel-Gaber, M.E.S. Ali, E. Khamis and S. El-Housseiny, Inhibitive action of Cannabis plant extract on the corrosion of copper in $0.5 \mathrm{M} \mathrm{H}_{2} \mathrm{SO}_{4}$, Int. J. Electrochem. Sci., 2013, 8, 7124-7137.

119. S. Gudić, E.E. Oguzie, A. Radonić, L. Vrsalović, I. Smoljko and M. Kliškić, Inhibition of copper corrosion in chloride solution by caffeine isolated from black tea, Maced. $J$. Chem. Chem. Eng., 2014, 33, no. 1, 13-25. doi: 10.20450/mjcce.2014.441

120. T. Ramde, S. Rossi and C. Zanella, Inhibition of the Cu65/Zn35 brass corrosion by natural extract of Camellia sinensis, Appl. Surf. Sci., 2014, 307, 209-216. doi: $\underline{10.1016 / j . a p s u s c .2014 .04 .016}$ 
121. M. Shabani-Nooshabadi, F.S. Hoseiny and Y. Jafari, Green approach to corrosion inhibition of copper by the extract of Calligonum comosum in strong acidic medium, Metall. Mater. Trans. A, 2015, 46, no. 1, 293-299. doi: 10.1007/s11661-014-2634-1

122. P. Deivanayagam, I. Malarvizhi, S. Selvaraj and P. Deeparani, Corrosion inhibition efficacy of ethanolic extract of mimusops elengi leaves (MEL) on copper in Natural Sea Water, Int. J. Multidiscip. Res. Develop., 2015, 2, no. 4, 100-107.

123. B.A. Abd-El-Nabey, S. El-Housseiny, G.A. El-Naggar, E.A. Matter and G. Esmail, Inhibitive action of Alhagi maurorum plant extract on the corrosion of copper in $0.5 \mathrm{M}$ $\mathrm{H}_{2} \mathrm{SO}_{4}$, Phys. Chem., 2015, 5, no. 3, 49-62. doi: 10.5923/j.pc.20150503.01

124. C. Rahal, M. Masmoudi, R. Abdelhedi, R. Sabot, M. Jeannin, M. Bouaziz and P. Refait, Olive leaf extract as natural corrosion inhibitor for pure copper in $0.5 \mathrm{M} \mathrm{NaCl}$ solution: A study by voltammetry around OCP, J. Electroanal. Chem., 2016, 769, 53-61. doi: 10.1016/i.jelechem.2016.03.010

125. H. S. Gadow, M.M. Motawea and H.M. Elabbasy, Investigation of myrrh extract as a new corrosion inhibitor for $\alpha$-brass in $3.5 \% \mathrm{NaCl}$ solution polluted by $16 \mathrm{ppm}$ sulfide, RSC Adv., 2017, 7, no. 47, 29883-29898. doi: 10.1039/C7RA04271J

126. F. Wedian, M.A. Al-Qudah and G.M. Al-Mazaideh, Corrosion inhibition of copper by Capparis spinosa L. extract in strong acidic medium: experimental and density functional theory, Int. J. Electrochem. Sci., 2017, 12, 4664-4676. doi: 10.20964/2017.06.47

127. R. Oukhrib, E. Issami, B. El Ibrahimi, K. El Mouaden, L. Bazzi, L. Bammou, A.Chaouay, S. Jodeh, B. Hammouti and A. Amin-Alami, Ziziphus lotus as green inhibitor of copper corrosion in natural sea water, Port. Electrochim. Acta, 2017, 35, no. 4, 187-200. doi: 10.4152/pea.201704187

128. S. Varvara, R. Bostan, O. Bobis, L. Găină, F. Popa, V. Mena and R.M. Souto, Propolis as a green corrosion inhibitor for bronze in weakly acidic solution, Appl. Surf. Sci., 2017, 426, 1100-1112. doi: 10.1016/j.apsusc.2017.07.230

129. A.S. Fouda and E.A. Haleem, Berry Leaves Extract as Green Effective Corrosion Inhibitor for Cu in Nitric Acid Solutions, Surf. Eng. Appl. Electrochem., 2018, 54, no. 5, 498-507. doi: $10.3103 /$ S1068375518050034

130. P. Refait, C. Rahal and M. Masmoudi, Corrosion inhibition of copper in $0.5 \mathrm{M} \mathrm{NaCl}$ solutions by aqueous and hydrolysis acid extracts of olive leaf, J. Electroanal. Chem., 2020, 859, 113834. doi: $10.1016 /$ j.jelechem.2020.113834

131. N.R. Short, S. Zhou and J.K. Dennis, Electrochemical studies on the corrosion of a range of zinc alloy coated steel in alkaline solutions, Surf. Coat. Technol., 1996, 79, no. 1-3, 218-224. doi: $10.1016 / 0257-8972(95) 02428-X$

132. P. A. Schweitzer, Fundamentals of metallic corrosion: atmospheric and media corrosion of metals, CRC press, 2006.

133. U.K. Chatterjee, S.K. Bose and S.K. Roy, Environmental degradation of metals: corrosion technology series/14, CRC Press, 2001. 
134. S.K. Rajappa, T.V. Venkatesha and B.M. Praveen, Chemical treatment of zinc surface and its corrosion inhibition studies, Bull. Mater. Sci., 2008, 31, no. 1, 37-41. doi: 10.1007/s12034-008-0007-3

135. O.K. Abiola and A.O. James, The effects of Aloe vera extract on corrosion and kinetics of corrosion process of zinc in $\mathrm{HCl}$ solution, Corros. Sci., 2010, 52, no. 2, 661-664. doi: 10.1016/j.corsci.2009.10.026

136. B.A. Abd-El-Naby, O.A. Abdullatef, A.M. Abd-El-Gabr, M.A. Shaker and G. Esmail, Effect of some natural extracts on the corrosion of zinc in $0.5 \mathrm{M} \mathrm{NaCl}$, Int. J. Electrochem. Sci., 2012, 7, 5864-5879.

137. F. Suedile, F. Robert, C. Roos and M. Lebrini, Corrosion inhibition of zinc by Mansoa alliacea plant extract in sodium chloride media: extraction, characterization and electrochemical studies, Electrochim. Acta, 2014, 133, 631-638. doi: 10.1016/j.electacta.2013.12.070

138. A.J. Chinweuba, Comparative Analysis of Corrosion Inhibition Properties of Allium Cepa Extract on Mild Steel and Zinc, J. Nat. Sci. Res., 2014, 4, no. 6, 1-6.

139. F.A. Ugbe, M.A. Funtua, A.V. Ikudayisi and A.A. Pam, Inhibitive and synergistic properties of ethanolic extract of Moringa oleifera leaves on the corrosion of zinc in $\mathrm{HCl}$ solution, Int. Res. J. Pure Appl. Chem., 2015, 331-341. doi: 10.9734/IRJPAC/2015/13915

140. B.U. Ugi, M.E. Obeten, T.O. Magu and I.E. Uwah, Corrosion Inhibition Performance Of Alkaloid Extracts Of Calendula Officinalis (Pot Marigold) Plant On Aluminium, Carbon Steel And Zinc In 5 M Nitric Acid Solution, Int. J. Innovative Res. Adv. Stud., 2016, 3, no. $12,34-40$.

141. H.A. Al Lehaibi, Control of zinc corrosion in acidic media: green fenugreek inhibitor, Trans. Nonferrous Met. Soc. China, 2016, 26, no. 11, 3034-3045. doi: 10.1016/S10036326(16)64434-5

142. J.N.O. Ezeugo, O.D. Onukwuli and M. Omotioma, Optimization of corrosion inhibition of Picralima nitida leaves extract as green corrosion inhibitor for zinc in $1.0 \mathrm{M} \mathrm{HCl}$, World News Nat. Sci., 2017, 15, 139-161.

143. A.E.A.S. Fouda, E.E. El-Katori and S. Al-Mhyawi, Methanol Extract of Slanum Nigrum as Eco-Friendly Corrosion Inhibitor for Zinc in Sodium Chloride Polluted Solutions, Int. J. Electrochem. Sci., 2017, 12, 9104-9120. doi: 10.20964/2017.10.64

144. C. Wang, J. Zhang, X.L. Chen, B. Xiang, J.Z. Duan and B.R. Hou, Inhibition of zinc corrosion by fucoidan in natural sea water, Acta Metall. Sin. (Engl. Lett.), 2017, 30, no. 6, 594-600. doi: 10.1007/s40195-016-0524-9

145. A.S. Fouda, S.M. Rashwan, M.M.K. Darwish and N.M. Arman, Corrosion inhibition of $\mathrm{Zn}$ in a $0.5 \mathrm{M} \mathrm{HCl}$ solution by Ailanthus altissima extract, Port. Electrochim. Acta, 2018, 36, no. 5, 309-323. doi: 10.4152/pea.201805309

146. D.J. Ezeugo, O.D. Onukwuli and M. Omotioma, Adsorption Kinetics of Picralima Nitida Seed Extract as a Green Corrosion Inhibitor for Zinc in $0.5 \mathrm{M} \mathrm{H}_{2} \mathrm{SO}_{4}$, Equat. J. Chem. Sci., 2018, 2, no. 1. 
147. R. Ixer, Minerals Handbook 1996-97. Statistics and Analyses of the World's Minerals Industry, Ed.: P. Crowson, Macmillan, London, 1996, 454.

148. M. Walia and G. Singh, Corrosion inhibition of pure nickel by some phosphonium compounds in acid medium, Surf. Eng., 2005, 21, no. 3, 176-179. doi: $\underline{10.1179 / 174329405 X 49976}$

149. A.D. Davydov, G.N. Korchagin and V.D. Kashcheev, Some Characteristics of the Electrochemical Machining of Ni in Long Channels, Elektron. Obrab. Mater., 1975, 4, 9-12.

150. C.F. Zinola and A.C. Luna, The inhibition of $\mathrm{Ni}$ corrosion in $\mathrm{H}_{2} \mathrm{SO}_{4}$ solutions containing simple non-saturated substances, Corros. Sci., 1995, 37, no. 12, 1919-1929. doi: 10.1016/0010-938X(95)00074-T

151. A.Y. El-Etre, M. Abdallah and Z.E. El-Tantawy, Corrosion inhibition of some metals using lawsonia extract, Corros. Sci., 2005, 47, no. 2, 385-395. doi: 10.1016/j.corsci.2004.06.006

152. A.Y. El-Etre and Z. El-Tantawy, Inhibition of metallic corrosion using Ficus extract, Port. Electrochim. Acta, 2006, 24, no. 3, 347-356. doi: 10.4152/pea.200603347

153. M. Abdallah, S.O. Al Karanee and A.A. Abdel Fattah, Inhibition of the corrosion of nickel and its alloys by natural clove oil, Chem. Eng. Commun., 2009, 196, no. 11, 14061416. doi: $10.1080 / 00986440902939053$

154. M. Abdallah, S.O. Al Karanee and A.A. Abdel Fatah, Inhibition of acidic and pitting corrosion of nickel using natural black cumin oil, Chem. Eng. Commun., 2010, 197, no. 12, 1446-1454. doi: 10.1080/00986445.2010.484982

155. B.A. Abd-El-Nabey, A.M. Abdel-Gaber, M.E. Said Ali, E. Khamis and S. ElHousseiny, Cannabis plant extract as inhibitor for the corrosion of nickel in $0.5 \mathrm{M}$ $\mathrm{H}_{2} \mathrm{SO}_{4}$, Int. J. Electrochem. Sci., 2012, 7, 11811-11826.

156. M. Abdallah, I.A. Zaafarany, S. Abd El Wanees and R. Assi, Corrosion behavior of nickel electrode in $\mathrm{NaOH}$ solution and its inhibition by some natural oils, Int. J. Electrochem. Sci., 2014, 9, no. 3, 1071-1086.

157. M. Nergaard and C. Grimholt, An Introduction to Scaling causes, problems and solutions, 2010, TPG4140 - Natural Gas, p5.

158. Z. Amjad and K.D. Demadis, Mineral Scales and Deposits, Scientific and Technological Approaches, 2015, 1st Edition, Elsevier.

159. A.C. Martinod, An Integrated Study of $\mathrm{CaCO}_{3}$ Formation and Inhibition, $\mathrm{PhD}$ thesis, University of Leeds, 2008.

160. B.A. Miksic, M.A. Kharshan and A.Y. Furman, Vapor corrosion and scale inhibitors formulated from biodegradable and renewable raw materials, European Symposium on Corrosion Inhibitors (10 SEIC), Ferrara, Italy, 2005.

161. NACE Standard Test Method, Laboratory Screening Tests to Determine the Ability of Scale Inhibitors to Prevent the Precipitation of Calcium Sulfate and Calcium Carbonate from Solution (for Oil and Gas Production Systems), Item № - 21208-SG, 2007. 
162. A.M. Abdel-Gaber, B.A. Abd-El-Nabey, E. Khamis and D.E. Abd-El-Khaled, Investigation of fig leaf extract as a novel environmentally friendly antiscalent for $\mathrm{CaCO}_{3}$ calcareous deposits, Desalination, 2008, 230, 314-328. doi: 10.1016/j.desal.2007.12.005

163. A.M. Abdel-Gaber, B.A. Abd-El-Nabey, E. Khamis and D.E. Abd-El-Khaled, A natural extract as scale and corrosion inhibitor for steel surface in brine solution, Desalination, 2011, 278, 337-342. doi: 10.1016/j.desal.2011.05.048

164. M. Bonoli, A. Bendini, L. Cerretani, G. Lercker and T.G. Tosci, Qualitative and semiquantitative analysis of phenolic compounds in extra virgin olive oils as a function of the ripening degree of olive fruits by different analytical techniques, J. Agric. Food Chem., 2004, 52, 7026-7032. doi: 10.1021/jf048868m

165. G. Maciejewska, W. Zierkiewicz, A. Adach, M. Kopacz, I. Zapala, I. Bulik, M. Cies'lak-Golonka, T. Grabowski and J. Wietrzyk, Atypical calcium coordination number: physicochemical study, cytotoxicity, DFT calculations and in silico pharmacokinetic characteristics of calcium caffeates, J. Inorg. Biochem., 2009, 103, no. 9, 1189-1195. doi: 10.1016/j.jinorgbio.2009.05.010

166. O.-H. Lee, B.-Y. Lee, J. Lee, H.-B. Lee, J.-Y. Son, C.-S. Park, K. Shetty and Y.-C. Kim, Assessment of phenolics-enriched extract and fractions of olive leaves and their antioxidant activities, Bioresour. Technol., 2009, 100, 6107-6113. doi: 10.1016/j.biortech.2009.06.059

167. A.M. Abdel-Gaber, B.A. Abd-El-Nabey, E. Khamis, H. Abd-El-Rhmann, H. Aglan and A. Ludwick, Green anti-scalant for cooling water systems, Int. J. Electrochem. Sci., 2012, 7, 11930-11940.

168. A. Viloria, L. Castillo, J.A. Garcia, M.A. Carrasquero Ordaz and E.V. Torin, Process using Aloe for inhibiting scale, United States Patent US 8,039,421 B2 (2011).

169. C. Woodward and E.A. Davidson, Structure-function relationships of protein polysaccharide complexes: specific ion-binding properties, Proc. Natl. Acad. Sci. U. S. A., 1968, 60, 201-205. doi: 10.1073/pnas.60.1.201

170. B. Suharso, S. Bahri and T. Endaryanto, Gambier extracts as an inhibitor of calcium carbonate $\left(\mathrm{CaCO}_{3}\right)$ scale formation, Desalination, 2011, 265, 102-106. doi: 10.1016/j.desal.2010.07.038

171. Z. Belarbi, J. Gamby, L. Makhloufi, B. Scotta and B. Tribollet, Inhibition of calcium carbonate precipitation by aqueous extracts of Paronychia argentea, J. Cryst. Growth, 2014, 386, 208-214. doi: 10.1016/j.jcrysgro.2013.09.048

172. J. Gamby, Z. Belarbi, L. Chaal, F. Guenole Chaussec, L. Makhloufi, B. Saidani, B. Tribollet and B. Sotta, Procédé de fabrication de produit antitartre, Patent WO2013132193 A1 (2013).

173. M. Chaussemier, E. Pourmohtasham, D. Gelus, N. Pécoul, H. Perrot, J. Lédion, H. Cheap-Charpentier and O. Horner, State of art of natural inhibitors of calcium carbonate scaling. A review article, Desalination, 2015, 356, 47-55. doi: 10.1016/j.desal.2014.10.014 
174. D.E. Abd-El-Khaleka, B.A. Abd-El-Nabey, M.A. Abdel kawi and S. Ramadan, Investigation of a novel environmentally friendly inhibitor for calcium carbonate scaling in cooling water, Desalin. Water Treat., 2016, 57, 2870-2876. doi: 10.1080/19443994.2014.987174

175. H. Wang, M. Gao, Y. Guo, Y. Yang and R. Hu, A natural extract of tobacco rob as scale and corrosion inhibitor in artificial seawater, Desalination, 2016, 398, 198-207. doi: 10.1016/j.desal.2016.07.035

176. Y. Bendaoud-Boulahlib and S. Ghizellaoui, Study of Inhibiting Effect of Orange peel on Hard Growth Water, J. Mater. Environm. Sci., 2017, 8, no. 3, 1076-1081.

177. Suharso, T. Reno, T. Endaryanto and Buhani, Modification of Gambier extracs as green inhibitor of calcium carbonate $\left(\mathrm{CaCO}_{3}\right)$ scale formation, J. Water Proc. Eng., 2017, 18, $1-6$.

178. Z. Mohammadi and M. Rahsepar, The use of green Bistorta Officinalis extract for effective inhibition of corrosion and scale formation problems in cooling water system, J. Alloys Compd., 2018, 770, 669-678. doi: 10.1016/j.jallcom.2018.08.198

179. A. Hajizadeh, T.B. Lotfabad and M. Bahmaei, Assessment of aqueous extract of Gypsophila aretioides for inhibitory effects on calcium carbonate formation, Green Process. Synth., 2019, 8, 464-473. doi: 10.1515/gps-2019-0014

180. G. Vasyliev, V. Vorobyova and T. Zhuk, Raphanus sativus L. Extract as a Scale and Corrosion Inhibitor for Mild Steel in Tap Water, J. Chem., 2020, 5089758. doi: $\underline{10.1155 / 2020 / 5089758}$

181. D.E. Abd-El-Khalek, B.A. Abd-El-Nabey, M.A. Abdel-kawi, Sh. Ebrahim and S.R. Ramadan, The inhibition of crystal growth of gypsum and barite scales in industrial water systems using green antiscalant, Water Supply, 2019, 19, no. 7, 2140-2146. doi: 10.2166/ws.2019.094

182. S.K. Hamdona, A.H.M. El-Aassar, H.A.H. Ibrahim, Abd El Monaem M. Ahmed and Abd El Salam Nasra, Green Inhibitor Antibacteria and Antiscaling in Reverse Osmosis Desalination Plants, CATRINA, 2019, 18, no. 1, 161-168.

183. S. Suharso, T. Tugiyono and H. Satria, Influence of gambier extract modification as inhibitor of calcium sulfate scale formation, Desalin. Water Treat., 2019, 169, 22-28. doi: $\underline{10.5004 / d w t .2019 .24664}$

184. P. Santoso, M.R. Setiawan and Suharso, Piper betle leaf extract as a green inhibitor of calcium sulphate $\left(\mathrm{CaSO}_{4}\right)$ scale formation, IOP Conf. Ser.: Earth Environ. Sci., 2019, 258, 012038. 